\title{
The Cypriot Constitution Under the Impact of EU Law: An Asymmetrical Formation
}

\author{
Constantinos Kombos and Stéphanie Laulhé Shaelou
}

\begin{abstract}
The Constitution of Cyprus (1960) is described in the report as unique and as a hybrid model. On the one hand, it has been seen as one of the world's most rigid and detailed constitutions; on the other hand, some parts are governed by the doctrine of necessity, given the division of the country. Special features include a strong protection of social rights and of the right to property; the protection granted to these and some other rights goes beyond the protection afforded by the ECHR. Cyprus has a mixed model of constitutional review. Fundamental rights based review is strong, with provisions interpreted in favour of the individual in cases of doubt. Resorting to constitutional amendments has become a tool for addressing issues related with the idiosyncrasies of the Cypriot Constitution. The use of this approach has become more frequent in the last two decades, whereas there had been a persistent refusal to amend the Constitution in the previous years. With regard to EU law, the Constitution has been amended to remove conflicts, including by virtue of Art. 1A, modelled loosely on the blanket EU clause of the Irish Constitution. At times, the amendments have even proved to be excessive, e.g. as regards an amendment pertaining to the EU Data Retention Directive that was subsequently annulled. The Constitution has also been amended to remove barriers to the European Arrest Warrant, alas in an incomplete way, at least initially; in parallel,
\end{abstract}

Constantinos Kombos is Associate Professor of Public Law, Law Department, University of Cyprus. e-mail: c.c.kombos@ucy.ac.cy.

Stéphanie Laulhé Shaelou is Professor of European Law and Reform and Head, School of Law, University of Central Lancashire, Cyprus. e-mail: SLaulhe-Shaelou@uclan.ac.uk.

Constantinos Kombos wrote Part 1 and Sects. 2.1, 2.4, 2.7, 2.9-2.13. Stéphanie Laulhé Shaelou wrote Sects. 2.2, 2.3, 2.5, 2.6, 2.8 and Part 3.

All websites accessed 15 July 2015. Text submitted 16 September 2015.

C. Kombos (ه)

Law Department, University of Cyprus, Nicosia, Cyprus

e-mail: c.c.kombos@ucy.ac.cy

S. Laulhé Shaelou

School of Law, University of Central Lancashire, Pyla, Cyprus

e-mail: SLaulhe-Shaelou@uclan.ac.uk

(C) The Author(s) 2019

A. Albi and S. Bardutzky (eds.), National Constitutions in European

and Global Governance: Democracy, Rights, the Rule of Law,

https://doi.org/10.1007/978-94-6265-273-6_29 
the initially rights-protective approach of Cypriot courts has gradually been watered down. The cases regarding EU sugar stocks measures raised issues regarding the principles of legitimate expectations and non-retroactivity of charges. The report raises the issue of a lack of debate about constitutional limits to EU law. It highlights the merits of a dissenting judicial opinion in the so-called 'bail-in' case that cautioned against elimination of the rule of law and judicial protection.

Keywords The Constitution of Cyprus - Constitutional amendments regarding EU and international co-operation • The Supreme Court of Cyprus • The 'necessity' doctrine $\cdot$ Judicial review $\cdot$ Fundamental rights and the rule of law Data Retention Directive and excessive constitutional amendment European Arrest Warrant - Defence rights - Judicial review and the statute of limitations • Property rights - Judicial dialogues and absence of constitutional limits Supremacy - 'Bail-in' case - Sugar stocks cases and the principles of legitimate expectations and non-retroactivity of charges - International extradition treaties

\section{Constitutional Amendments Regarding EU Membership}

\subsection{Constitutional Culture}

1.1.1 The Cypriot constitutional paradigm is unique in content and atypical in character, and it can be argued that as such it has no comparative parallel at the international level. That is manifested in two main ways.

First, there is the peculiarity of the constitutional setting whereby there is a stark and material difference between the provisions of the Constitution of 1960 and their actual application since 1964, when the doctrine of necessity was introduced by the Supreme Court in the landmark judgment Ibrahim. ${ }^{1}$ The doctrine of necessity has redefined constitutional law and created two parallel constitutional worlds. On the one hand, there are the constitutional provisions that remain in full formal force; they provide for a bi-communal structure that assumes the presence and participation of both Turkish and Greek Cypriots and for a constitutional system with organs of the state that are reflective of bi-communalism and with a plethora of strict checks and balances on the same basis. This can be called 'the silent Constitution'. On the other hand, there is the ad hoc suspension of the invalidity rule that attributes hierarchical supremacy to the Constitution of 1960 in those instances that can be justified under the doctrine of necessity. This can be called 'the pragmatic Constitution'.

Therefore, the primary peculiarity of the Cypriot constitutional system is that both 'Constitutions' coexist to the point where a constitutional provision and

\footnotetext{
${ }^{1}$ The Attorney General of the Republic v. Mustafa Ibrahim [1964] CLR 195. For analysis see Kombos 2015a, b; Polyviou 2013, pp. 26-64; Polyviou 2015a, pp. 32-124; 2015b.
} 
constitutional reality are two completely different things. For example, Art. 1 provides for a Turkish-Cypriot Vice-President, but no such official has assumed duties since 1963. Moreover, the Constitution in Art. 133(1) provides for a Supreme Constitutional Court composed of three members (a Turkish-Cypriot, a Greek-Cypriot and a presiding non-Cypriot). Since 1964, there is instead a Supreme Court that was founded on the basis of Law 33/64, which included provisions that were in direct contradiction with Art. 133. Nonetheless, the Supreme Court continues to function regardless of the rule in Art. 179 of the Constitution that attributes hierarchical supremacy to the constitutional provisions.

At this point, it is useful to elaborate on the doctrine of necessity, which was introduced on the basis of the founding premise that the Constitution exists for the state and when the state is in grave danger of collapse, constitutional provisions have to give way. In response to this dilemma, the Supreme Court enabled the suspension of the application of certain fundamental constitutional provisions yet without in any way altering any of those provisions in the formal sense. The doctrine of necessity is an atypical response to an atypical constitutional situation and is now in its fifth decade in Cyprus. ${ }^{2}$ Therefore, the constitutional provisions remain fully effective in theory but where the doctrine of necessity is applied, their content and effectiveness is numbed, neutralised and non-applicable. The preceding approach can be explained by reference to the German theoretical perception that distinguishes between the concept of hierarchical supremacy leading to invalidity (Geltungsvorrang) and the concept of priority in application (Anwendungsvorrang). Where the doctrine of necessity applies, the constitutional norm is rendered non-applicable in an exceptional and extraordinary manner, thus removing the invalidity (Geltungsvorrang) function and, as a corollary, the contested legal norm acquires a de facto priority in application (Anwendungsvorrang). ${ }^{3}$

Therefore, the classic perception that emphasises the distinction between 'Constitution' and 'constitutional law' is especially relevant to the Cypriot context, given the fact that the Constitution of 1960 must be read in the light of the doctrine of necessity that, since 1964, offers the pillar on which the Constitution relies for its preservation. In this vein, 'Constitution' refers to the constitutional provisions of the Constitution of 1960, while 'constitutional law' refers to the application of those provisions through the filter of the doctrine of necessity. Through the Ibrahim judgment, the doctrine of necessity in effect redefined the scope, content, structure and philosophy of the Constitution, yet without formally amending any of its provisions. ${ }^{4}$

The second distinctive character of the Cypriot constitutional context relates to the judicial approach that is characterised by cosmopolitanism and by a traditional reliance on the comparative methodology. ${ }^{5}$ It can be argued that the national system

\footnotetext{
${ }^{2}$ Loizou 2001, pp. 12-31; Nicolaou 2000, pp. 105-34; Evriviades 1975; Tornaritis 1980, pp. 5477.

3 Kombos 2015a, Chap. 2.

${ }^{4}$ Kombos 2015a.

${ }^{5}$ Kombos 2015b, Chap. 3; Hatzimihail 2013.
} 
was developed with direct references to foreign jurisdictions. The nexus with comparative law as a special feature of the Cypriot legal order has been explained with reference to historical factors. ${ }^{6}$ These relate to the organic evolution of the legal system, thus classifying Cyprus as part of 'the mixed-jurisdictions sub-genre'. ${ }^{7}$ This argument is supported with reference to the areas of family law and contract law $^{8}$ where there is a considerable body of evidence pointing to a strong presence of common law principles. For example, Hatzimihail argues that the three main Codes of the Cypriot legal system are directly derived from common law and especially from the Nigerian Criminal Code, the Indian Contract Code and also the Indian Civil Wrongs Code.

In the field of public law, the creation and evolution of administrative law has been marked by the strong influence of the Greek droit administratif. ${ }^{9}$ This is evident in the form of frequent reliance on Greek academic works and on the case law of the Greek Conseil d'Etat, to the point where it is reasonable to argue that it is rare to find a decision in the area of administrative law where reference is not made either directly or indirectly to Greek academic works and/or Greek jurisprudence. It must be noted that the codification of administrative law took place in 1999, and thus until that point the evolution of administrative law by the Supreme Court took place on a case-by-case basis.

The Cypriot legal system has also more generally used the comparative method either as an independent source of law or as an auxiliary tool for supplementing existing constitutional provisions. Reference to foreign jurisdictions extends beyond the Greek context. ${ }^{10}$

The use of the comparative method - strong in intensity and dense in frequency - is indicative of a willingness of the Supreme Court to be open to external sources of influence. This characteristic of the judicial approach represents a benchmark for analysing the degree and form of receptiveness that the Supreme Court has illustrated in relation to EU law. The peculiarity relates to the scale and intensity of the use of the comparative method on the one hand, and to the unjustified entrenchment of EU law concepts and principles on the other.

As a corollary, the rather bold opening statement about the uniqueness of the Cypriot constitutional system is not an exaggerated claim influenced by an inherent 'need' to give priority and importance to the national constitutional idiosyncrasies and peculiarities. Moreover, the preceding statement is not an expression of constitutional patriotism dictated by an anachronistic inward approach to public law

\footnotetext{
${ }^{6}$ Hatzimihail 2013.

${ }^{7}$ Ibid., p. 39.

${ }^{8}$ Ibid.

${ }^{9}$ Hatzimihail 2013, p. 79.

${ }^{10}$ Kombos 2015b, Chap. 3; Hatzimihail 2013.
} 
that is dictated by a pre-existing familiarity with national legal doctrines and thought. $^{11}$

Overall, the Cypriot constitutional culture reflects the normative and conceptual modifications that have affected the system after the application of the above-mentioned doctrine of necessity that has redefined constitutional law in pragmatic terms. ${ }^{12}$ Accordingly, the Cypriot example can be classified in a hybrid category that falls between classical and evolutionary constitutions. ${ }^{13}$ The former tend to have a strict and pure legal character that is founded on rigidity, normative hierarchy and effective judicial protection, while the latter tend to be more evolutionary, historic and political in nature. ${ }^{14}$ In the case of Cyprus, the Constitution of 1960 is founded on strict adherence to the hierarchical supremacy of the constitutional provisions (Art. 179), combined with a permanency of the system that is reflected in the long list of unamendable provisions (Art. 182 and Annex III) whereby 48 out of the 199 constitutional provisions have perpetual status. It must be noted that in that list, only one article relates to fundamental human rights (Art. 23 on the right to property). To that effect, De Smith has argued that the Constitution of 1960 is 'the most rigid, detailed and complicated constitution in the world', ${ }^{15}$ and has also stated that

[t]he Constitution of Cyprus is ... weighted down by checks and balances, procedural and substantive safeguards, guarantees and prohibitions. Constitutionalism has run riot in harness with Communalism. The Government of the Republic must be carried on, but never have the chosen representatives of a political majority been set so daunting an obstacle course by the constitution makers. ${ }^{16}$

Therefore, the Cypriot constitutional system is inherently a classical Constitution yet with certain important and influential special features. First, the Constitution is the outcome of international law applied in an unusual form. Specifically, the nature of the process of decolonisation and the actual method for the transfer of power to a newly formed independent state in 1960 were decided in principle and also in detail in Zurich, by Greece and Turkey, in the physical absence of the legally responsible entity that was the colonial power (Great Britain). That paradox is significant, as Great Britain within days of the conclusion of the international agreement between Greece and Turkey stated its acceptance of all the terms with just one single addition in relation to the status of the military bases that it was to retain on the island. The Zurich agreement had 17 points that would form the organisational core of the new state, and those were to create the framework and the content of the new Constitution. Thus, the right of self-determination and, more importantly, the right to exercise primary constitutive power found no expression in the case of Cyprus.

\footnotetext{
${ }^{11}$ Legrand 2002, pp. 246 and 255.

12 Soulioti 2006.

${ }^{13}$ Birkinshaw and Kombos 2009; Kombos 2010a.

${ }^{14}$ Besselink 2006, p. 113 et seq.; Albi 2005, p. 22 et seq.

${ }^{15}$ De Smith 1964, p. 285.

${ }^{16}$ Ibid.
} 
No referendum was called and no constituent assembly was formed. Secondly, the Cypriot example is also characterised by the attribution of the role of guardian to Great Britain, Greece and Turkey through the Treaty of Guarantee. Their role included the safeguard of the constitutional status quo, thus creating an impasse in the event of the need to modify the Constitution and its philosophy because of functionality problems. Thus the Cypriot Constitution is simultaneously a classical constitution and also deviates from that blueprint due to the restriction of the exercise of constitutive power at the moment of inception and at any later stage.

At the same time, the Cypriot constitutional system is undoubtedly also an evolutionary constitution because the application of the doctrine of necessity after Ibrahim has created a parallel constitutional world, as explained above. Nonetheless, the maintenance at a formal and normative level of the original Constitution, even after the application of the doctrine of necessity, has the effect of excluding the characterisation of the system as purely evolutionary.

By way of summary, the Cypriot paradigm thus represents a hybrid model that does not fall in either of the two categories in a mutually exclusive manner, but rather belongs to both categories.

1.1.2 The position of the Constitution in such an open and evolving constitutional system that has been redefined in a fundamental way by the doctrine of necessity remains central with regard to the rationale of the judiciary. The rationale and the role of the Constitution remain paramount in the sense of ensuring full effective judicial protection, the rule of law, separation of powers and the principle of legality. The concept of sovereignty and the organisation of the state take a subsidiary role in the approach of the Court for different reasons. As regards the organisation of the state, the doctrine of necessity has an important impact, since it enables the restructuring of state organs in order to ensure functionality. In terms of the concept of sovereignty, the Supreme Court has in the past placed emphasis on the need to preserve the formal status of constitutional provisions by restricting the possibility of amendments as a way to ensure the preservation of the Republic at the level of public international law (see Sect. 1.2). Overall, the emphasis is on the rule of law and effective judicial protection, and these can be considered to be the foundations for the judicial approach towards the Constitution.

The Courts have to strike a delicate balance between the actual constitutional provisions and the application of the doctrine of necessity; in general, two categories of cases can be identified. First, there are the cases where the full application of a constitutional provision is not possible due to the withdrawal of the Turkish-Cypriot Community, thus triggering the application of the doctrine of necessity. Secondly, there are the cases where a constitutional provision has remained unaffected by the withdrawal of the Turkish-Cypriots and, in those instances, the Constitution remains the paramount guiding source. One such area is the protection of fundamental rights that the Constitution fully provides for in Part II. ${ }^{17}$ In such cases the doctrine of necessity has remained non-applicable almost

${ }^{17}$ Kombos and Pantazi 2012; Kombos et al. 2015. 
entirely ${ }^{18}$ because the Court places the centre of gravity on the protection of fundamental rights (see Sect. 2.2).

One special feature of the Cypriot Constitution in relation to fundamental rights that can be seen as part of the national constitutional identity is the protection of social rights. The Constitution by a series of articles guarantees the individual certain social and economic rights, which are to be exercised within the framework of the public interest and common good (see Sects. 2.1-2.2).

\subsection{The Amendment of Constitution in Relation to the European Union}

1.2.1-1.2.4 Prior to EU accession, the Constitution was amended in relation to the EU only as regards the independence of the Central Bank. The Fourth Constitutional Amendment, introduced by Law 104 (I)/2002, amended Arts. 147, 118 and 119 of the Constitution to ensure the independence of the Central Bank in terms of restricting the dismissal of the Governor and also to exclude any political supervision of the Bank.

After EU accession, the Constitution was amended in 2006 by the Fifth Amendment of the Constitution Law $^{19}$ in order to accommodate the introduction and application of the basic principles of EU law.

By way of the history of its introduction, during the lengthy process of implementation of the acquis communautaire, the need to amend the Constitution was considered, and a formal recommendation was made to extensively amend the Constitution in order to facilitate accession to the European Union. ${ }^{20}$ However, at first the decision was taken that such a course of action was not necessary for three main reasons that are related to the external recognition of the Republic, to the limits of the doctrine of necessity and to the complexity of the provision governing constitutional amendments. In particular, the Supreme Court initially, ${ }^{21}$ in the 1980s, rejected attempts to amend the Constitution on the basis that the votes of the Turkish-Cypriot Members of Parliament were required under Art. 182(3) of the Constitution. This could have been remedied through the doctrine of necessity. Nonetheless, the approach of the Supreme Court was to reject the use of the doctrine, which is deemed an exceptional measure to be used in the most extreme situations where the existence of the state is endangered. As such, its application

\footnotetext{
${ }^{18}$ For the rare examples where the opposite applied see Kombos 2015a, Chap. 6.

${ }^{19}$ Law No. 127(I)/2006, Official Gazette No. 4090, 28.7.2006, Annex I(I), p. 1372, available in English at http://www.olc.gov.cy/olc/olc.nsf/all/EC240D2A9413ABBB4225793A00403484/\$file/ The $\% 20$ Fifth $\% 20$ Amendment $\% 20$ of $\% 20$ the\%20Constitution\%20Law\%20of\%202006.pdf? openelement.

${ }^{20}$ Lycourgos 2010, pp. 102-03.

${ }^{21}$ President of the Republic v. House of Representatives [1985] 3 CLR 2224; President of the Republic v. House of Representatives [1986] 3 CLR 1439.
} 
must have a temporary effect. A constitutional amendment would have a permanent effect, and hence the doctrine of necessity cannot be used to enable the enactment of a constitutional amendment. ${ }^{22}$ Although that approach was subsequently reversed, the crucial point is that the rationale against constitutional amendments remained relatively strong and influential.

In relation to EU accession, it was thought that a solution would be found through a judicial method whereby the provisions of the Constitution would be interpreted in the light of Art. 169 of the Constitution that refers to the status of international treaties and also in the light of the doctrine of necessity. As a result, it was hoped that the courts would enable the effective and efficient participation of the Republic in the EU by harmoniously construing the obligations arising from EU membership with national constitutional law.

The key in the preferred approach was Art. 169(3) of the Constitution that grants superior force against any conflicting municipal law to ratified Treaties (see Sects. 3.1-3.2). This basic rule was supplemented by the adoption of Law No. 35(III)/2003, with which the House of Representatives approved the ratification of the Accession Treaty. The Law contained the important Art. 4, which stated in clear terms that ' $[\mathrm{t}]$ he rights and obligations deriving from the Treaty [of Accession] are directly applicable in the Republic and take precedence over any contrary legal or regulatory provision'. The formula used secured the primacy of EU law against all conflicting acts originating from national law, yet it fell short from regulating the relationship between national constitutional law and EU law.

This obvious shortcoming emerged in Attorney General of the Republic $v$. Costas Constantinou. ${ }^{23}$ The case concerned the implementation of the European Arrest Warrant (EAW) Framework Decision (FD) ${ }^{24}$ by Law 133(1)/2004, and the issuing of an order to surrender Mr. Constantinou to the United Kingdom, which will be discussed in greater detail in Sect. 2.3. The Supreme Court held that the Framework Decision could not prevail over Art. 11 of the Constitution that expressly prohibits the extradition of Cypriot nationals, ${ }^{25}$ despite the fact that the Supreme Court acknowledged the case law of the Court of Justice of the European Union (CJEU) on the principle of primacy of EU law. Accordingly, the Supreme Court declared the incompatibility of the national implementing law with the Constitution, which according to Art. 179 of the Constitution renders the law invalid. Moreover, the Supreme Court in effect indirectly dictated the need for a constitutional amendment without stating so, thus giving the impression that the solution remains within the exclusive powers of the other branches of the state. This approach is in line with the principle of separation of powers, but it also creates an understanding that the subsequent normative accommodation of the primacy of EU

\footnotetext{
${ }^{22}$ Kombos 2015a, Chap. 6.

${ }^{23}$ [2005] 1 CLR 1356.

${ }^{24}$ Council Framework Decision of 13 June 2002 on the European arrest warrant and the surrender procedures between Member States (2002/584/JHA), [2002] OJ L 190/1.

${ }^{25}$ Attorney General v. Afamis 1 R.S.C.C 121.
} 
law with regard to the Constitution must be full in order to ensure future compliance with the yardstick that the Court applied in Constantinou. It is in this light that one must read the subsequent Fifth Constitutional Amendment that, as will be explained below, had an unnecessarily extensive scope.

The Court on first sight safeguarded the hierarchy of the Constitution, but at the same time it opened the door for the redefinition of that hierarchical position. This was perhaps a clear outcome dictated by express constitutional provisions that limited the room for harmonious interpretation, but at the same time the open-ended invitation to amend the Constitution without defining the limits of what could be acceptable represents a serious shortcoming. Such an approach contradicts the traditional vigilance that the Supreme Court has shown with regard to constitutional amendments. In addition, the decision could be contrasted with that of the German Bundesverfassungsgericht in the Lisbon Judgment, ${ }^{26}$ which provides an interesting example of the 'proactive approach', representing a judicial pronouncement - at the earliest possible opportunity - on what would interfere with the Constitution and the separation of powers.

In terms of the content and character of the Fifth Constitutional Amendment, which, as noted earlier, was introduced (two years) after EU accession in 2006, the original idea was to ensure the primacy of EU law in one single article of the Constitution that would then function as the point of reference for any incompatibility arising between EU law and national constitutional law. This is now Art. 1A of the Constitution. Nonetheless, it must be noted that despite the fact that introduction of an umbrella provision was the selected model, the provisions of the Fifth Constitutional Amendment took a completely different form in terms of methodology and approach. There were instead a nexus of constitutional provisions that were amended in addition to the introduction of the single umbrella provision: in addition to Art. 1A, a paragraph was added to Arts. 140 and 169, and alterations were made to Arts. 11(2) and 179 of the Constitution.

Specifically, Art. 1A states:

No provision of this Constitution shall be considered as invalidating laws enacted, acts done or measures adopted by the Republic necessitated by its obligations as a Member State of the European Union or shall prevent Regulations, Directives or other acts or binding measures of a legislative character adopted by the European Union or by the European Communities or by their institutions or by their competent bodies under the provisions of the treaties founding the European Communities or the European Union, from having legal effect in the Republic.

It is submitted that there is a crucial problem with Art. 1A, and that problem has both formal and substantial aspects. Formally, as explained above, Art. 182(1) of the Constitution, read in combination with Annex III of the Constitution, creates a long list of non-amendable articles of the Constitution, which includes Art. 1. The addition of para. A to Art. 1 is only indirectly justified in the Preamble of the Fifth Constitutional Amendment Law as not amounting to a constitutional amendment of

${ }^{26}$ BVerfG, Judgment of 30 June 2009 - 2 BvE 2/08 - Rn. (1-421). 
a basic constitutional provision. It is submitted that this approach is not correct and is at best playing with formalism, because an addition to any article of the Constitution cannot be construed as anything other than a constitutional amendment. At the same time, the insertion in Art. 1 was deliberate in order to pre-empt any future constitutional amendment. Moreover, it is submitted that the issue is made clear by Art. 182 of the Constitution:

1. The Articles or parts of Articles of this Constitution set out in Annex III hereto which have been incorporated from the Zurich Agreement dated 11th February, 1959, are the basic Articles of this Constitution and cannot, in any way, be amended, whether by way of variation, addition or repeal.

2. Subject to para. 1 of this Article any provision of this Constitution may be amended, whether by way of variation, addition or repeal, as provided in para. 3 of this Article.

3. Such amendment shall be made by a law passed by a majority vote comprising at least two-thirds of the total number of the Representatives belonging to the Greek Community and at least two-thirds of the total number of the Representatives belonging to the Turkish Community.

Accordingly, there is a clear question about the constitutionality of the Law introducing the Fifth Constitutional Amendment. There has never before or since been any amendment of a basic constitutional provision.

Moreover, besides Art. 1A, further amendments were introduced to other parts of the Constitution - Arts. 11(2), 140, 169 and 179.

Lastly, it would have been expected that the Supreme Court would have at least examined even as obiter the nature and even validity of the introduction of Art. 1A; this has never happened so far. Yet, it is imperative that the Supreme Court take a position on the matter, as the issue exceeds by far the matter of primacy of EU law.

Furthermore, it would have been preferable to implement the choice of introducing an umbrella clause by amending Art. 179, which guarantees the supremacy of the Constitution and, in terms of structural coherency, it would have represented the obvious place for such a clause. As to the possible argument that Art. 179 could be further amended in the future and thus it would not present a permanent solution, the answer has three parts. First, it is not axiomatic that the Republic should make the acceptance of the principle of primacy of EU law perpetually permanent, as it can theoretically decide to exit the Union. Secondly, the introduction of the principle of primacy of EU law in Art. 179 would have the same permanency as that of Art. 1A, since nothing would restrict the House of Representatives from repealing that paragraph. Thirdly, one must balance the importance of accommodating the principle of primacy of EU law in a permanent way with the need to safeguard the non-amendable nature of the fundamental constitutional provisions, which is by far and without question the most important consideration.

The next step in the normative solution was to complement Art. 1A with the amendment of the non-basic provisions to be found in Arts. 169, 179, 140 and 11 of the Constitution. Article 179, in its amended form, reads as follows: 
1. Without prejudice to the provisions of Art. 1A, the Constitution shall be the supreme law of the Republic.

2. No law or decision of the House of Representatives or of any of the Communal Chambers and no act or decision of any organ, authority or person in the Republic exercising executive power or any administrative function shall in any way be repugnant to, or inconsistent with, any of the provisions of this Constitution or any obligation imposed on the Republic as a result of its participation as a Member State in the European Union.

In terms of the effect of the preceding provision, Lycourgos correctly observes that:

[t]he combined effect of the new Art. 1A and of Art. 179 as amended, is that not only Community law but also EU law has been recognized as taking precedence over the Constitution. In that respect, the principle enshrined in the Constitution of the Republic of Cyprus preceded even the case law of the ECJ, which never expressly held that the acts adopted under the Union's third pillar - as it was at the time the fifth constitutional amendment - had precedence over national constitutional provisions. ${ }^{27}$

However, from the preceding approach arises a serious substantive problem: it had, at the time, the effect that the Republic of Cyprus gave a more extensive scope and effect to the principle of primacy of EU law than what the jurisprudence of the $E C J$ required. Although the issue has lost its relevance since the entry into force of the Lisbon Treaty, before that, the EU and the EC dimension had clearly been distinguished under Union law, with the ECJ jurisdiction having been limited in relation to the Second and Third Pillars. This in a comparative perspective is perhaps unprecedented. The Supreme Court remained silent on the issue.

The remaining amendments concerned Art. 11(2) in relation to extradition under the European Arrest Warrant, which will be explored in Sect. 2.3, and Arts. 140 and 169, which will subsequently be explored here.

Under Art. 140, as applied after 1964, the President of the Republic may, prior to the promulgation of any law or decision of the House of Representatives, refer to the Supreme Court for its opinion as to whether such act is inconsistent with the Constitution. With the Fifth Constitutional Amendment, this power was extended to the compatibility of a law or decision of the House of Representatives with the "law of the European Communities or of the European Union'.

The difficulty arises from the way in which the power of the President is exercised in practice. Traditionally, the Art. 140 power was exercised in instances of a clear difference of opinion between the President and the Parliament and on matters having a non-negligible political dimension and/or affecting the balance of powers and/or impacting on the proper interpretation of the Constitution. In addition, the Attorney General advises the President on the propriety of making use of Art. 140 and in practice, the view of the Attorney General is crucial. Compliance with the often technical requirements of the obligations arising from EU law creates a different setting, where the advisory role of the Attorney General is expected to be

${ }^{27}$ Lycourgos 2010, p. 105. 
broadened; it marks a considerable shift towards a stronger advisory role of the Attorney General.

As regards the extension of this jurisdiction to compatibility with EU obligations, it must be stressed that the point of reference for the exercise of the jurisdiction by the Supreme Court changes. The issue could very likely become one of interpretation of what the EU obligations entail, thus opening the way for a preliminary reference to the CJEU. In the event of a preliminary reference, the status of the law will remain pending until the CJEU responds, thus creating, as Lycourgos correctly argues, an issue of propriety and compliance with the principle of separation of powers. ${ }^{28}$ The alternative for the Supreme Court would be to deliberately avoid making a preliminary reference, thus distancing the Court from the correct application of Art. 267 TFEU. Therefore, the amendment of Art. 140 of the Constitution seems to be creating more problems than it solves.

One such notable example was evident in President of the Republic v. House of Representatives, ${ }^{29}$ which concerned non-compliance with Directive 2000/13/EC on the approximation relating to the labelling, presentation and advertising of foodstuffs, ${ }^{30}$ which required that all national implementing measures relating to the sale of genetically modified foodstuffs in supermarkets had to be notified to the European Commission and the other Member States. Moreover, only after three months following that notification and only if the Commission did not issue a negative opinion could the national measures be introduced. An amendment to the Foodstuffs (Control and Sale) Law came within the scope of the Directive, but the notification procedure had not been followed. As a result and on the advice of the Attorney General, the President proceeded to refer the Law via the amended Art. 140 of the Constitution. The Supreme Court found that there was an apparent procedural error that resulted in non-compliance with the EU obligations. The finding in this case was relatively straightforward, as the issue was one of apparent procedural infringement; however the same cannot be said in relation to more complex situations.

One such complex situation arose in Reference 2/2013, President of the Republic v. House of Representatives. ${ }^{31}$ The case concerned a conflict between a Law adopted in 2012 on the protection of the seaside and the Services Directive. ${ }^{32}$ The national Law, in which priority was given to the owner or operator of a seaside hotel or recreational business in relation to the tender procedure for leasing the relevant part of the beach, went against the Directive's requirement that the licensing system should not be discriminatory and disproportionate. In this case, which will be explored in greater detail in Sect. 2.2, the President referred the

\footnotetext{
28 Ibid., p. 107-08.

29 [2008] 3 CLR 118.

${ }^{30}$ [2000] OJ L 109/29.

319 May 2014.

32 Directive 2006/123/EC of the European Parliament and of the Council of 12 December 2006 on services in the internal market, [2006] OJ L 376/36.
} 
incompatibility to the Supreme Court under Art. 140 of the Constitution. The decision of the Supreme Court made note of the CJEU case law that the Attorney General cited in his argumentation, but at the same time the Court did not make any specific reference to those cases. Moreover, the issue concerned the application of the principle of proportionality, which by nature has an element of subjectivity and creates room for different approaches. However, the Supreme Court was unanimous in deciding that there was an apparent incompatibility between the Law and the Directive. The matter in this case was one of substance rather than procedure, and the Court made the correct assessment. Nevertheless, the assessment was much more complex than that necessitated in the earlier case, which gives rise to concerns relating to the selection of instances where Art. 140 is used and the manner of deciding such cases in the context of a preliminary reference.

Finally, there is also a technical issue regarding a gap that has emerged in relation to secondary legislation (i.e. regulations, etc., introduced by the executive but the approval of which is to be decided by the legislature) that is often the means used for completing the implementation of directives. Such measures cannot be the subject of a reference under Art. 140, since under Arts. 51 and 140 of the Constitution, the President is not required to sign them. The issue came to the surface in the aftermath of the Supreme Court decision in the same case, Reference 2/2013. The House of Representatives had modified regulations submitted by the executive that were intended to comply with the provisions of the Services Directive in the context of the licensing system that would apply for seaside establishments wishing to take commercial advantage of the seaside (sunbeds, water sports, etc.). The relevant regulations that the House of Representatives had adopted introduced a discriminatory scheme whereby it was considered an advantage if an applicant for a license had experience (5 years) in providing services in the specific area. Therefore, despite the earlier ruling of the Supreme Court and the clear provision of the Directive, the adopted regulations reintroduced a discriminatory system. According to Cypriot constitutional law, secondary legislation cannot be the subject of a reference under Art. 140. Consequently, the problem of incompatibility arose and resulted in the Ministry of Interior asking the local authorities to not comply with the regulations on the basis of the ECJ decision in Fratelli Costanzo. ${ }^{33}$ There the ECJ held that 'administrative authorities, including municipal authorities, are under the same obligation as a national court to apply the provisions of... [a] Directive and to refrain from applying provisions of national law which conflict with them, ${ }^{34}$ provided that the relevant provision has direct effect. ${ }^{35}$ According to related case law of the ECJ, the scope of application must be construed in the light of the principles of national procedural autonomy and national institutional autonomy. Therefore, an interesting gap in relation to Art. 140 of the Constitution exists that creates further doubts as to its effectiveness,

\footnotetext{
${ }^{33}$ Case C-103/88 Fratelli Costanzo v. Commune di Milano [1989] ECR 01839.

${ }^{34}$ Ibid., para. 33.

${ }^{35}$ Ibid., paras. 29-32.
} 
given its non-applicability to secondary legislation. Moreover, attempts are made to fill the gap in by relying on the Fratelli Costanzo rule which has, as its basic precondition, the direct effect of the EU law provision. But the issue then arises as to who has the authority to make such a complicated determination, since the obligation to apply such secondary legislation often rests on administrative authorities. This creates issues of legal certainty, expertise and separation of powers. All of these matters surfaced in the example in question and, at the time of writing, the outcome is uncertain.

To summarise, it must be questioned whether the constitutional amendment of Art. 140 of the Constitution was necessary given the problems arising from its application and the rarity of its use.

The Fifth Constitutional Amendment additionally added a new para. 4 to Art. 169 to the Constitution, which reads as follows:

4. The Republic may exercise every choice and discretion provided for in the Treaties establishing the European Communities and the Treaty on European Union and in any Treaties which amend or replace the above and which are concluded by the Republic.

This provision and its rationale are once again forward-thinking. The provision shields the national act related with the exercise of the option from scrutiny as to its constitutionality. The question is whether it should, given that there is a clear distinction between obligation and option. The ECJ founded the creation of primacy of EU law on the basis of a paramount need for the effectiveness, uniformity and structural coherence of the legal system of the Union. The justifying rationale for the principle of primacy of EU law, however, does not apply to the exercise of options by Member States before they decide to make use of their discretion. Therefore, the amendment of Art. 169 cannot be justified with reference to the need to comply with the principle of primacy of EU law.

The Constitution was subsequently further amended in 2010 (Sixth Amendment, of Art. 17 of the Constitution) with regard to the Data Retention Directive ${ }^{36}$ in the aftermath of the Supreme Court judgment in Alexandrou; the details will be provided in Sect. 2.4.

Finally, Art. 11 of the Constitution was amended on a further occasion in 2013 by introducing the Seventh Amendment of the Constitution via Law 68(I)/2003, in order to allow the extradition of Cypriot citizens in connection to events that took place at any time even before accession to the EU; the details will be provided in Sect. 2.3.

In general, the opinions of legal scholars were not requested during the process of introducing the above amendments, with the exception of the Fifth Constitutional amendment for which consultation took place, at an earlier stage of the discussion, about the need for a full revision of the Constitution. At the time of writing, no

\footnotetext{
${ }^{36}$ Directive 2006/24/EC of the European Parliament and of the Council of 15 March 2006 on the retention of data generated or processed in connection with the provision of publicly available electronic communications services or of public communications networks and amending Directive 2002/58/EC, [2006] OJ L 105/54.
} 
other constitutional amendments relating to EU law are being discussed; however there are areas where such discussion could be useful. For instance, the whole logic of the Fifth Constitutional Amendment, as explained previously, needs to be re-examined since it is problematic and overly expansive. In addition, the Sixth Constitutional Amendment is now equally problematic given that the Data Retention Directive has been annulled by the CJEU.

\subsection{Conceptualising Sovereignty and the Limits to the Transfer of Powers}

1.3.1 The provisions on supremacy of EU law were provided in Sect. 1.2.

1.3.2 The issue of the transfer or delegation of powers to the EU has not been at the epicentre of the debate in Cyprus because the prevailing view sees participation in the EU as a matter of political determination that was expressed through accession to the Union. Therefore, any delegation or transfer of competences is understood as an expression of the will of the sovereign state and as a matter of choice that attracts the full accommodation of the international obligations of the Republic. If such membership requires the effective transfer or delegation of powers and if that in practice commands the amendment of the Constitution, then any such adjustment is perceived as being nothing more than the expression of the Republic's will. On this basis, the Fifth Constitutional Amendment and the previous decision of the Supreme Court in Constantinou can both be explained as an expression of the intention to participate in the EU system and as a voluntary limitation of powers.

1.3.3 Nonetheless, the extensive scope of the Fifth Constitutional Amendment, as explained in detail above, is so open-ended that it significantly constrains any room for disagreement. This is problematic because the Supreme Court has so far failed to develop a reservation formula that would set limits as to what is constitutionally acceptable. Moreover, this approach places Cyprus in the minority of Member States that have accepted the principle of primacy of EU law without serious reservations. Put differently, the Cypriot approach is purely national in nature and founded on what the Constitution provides in the aftermath of the amendment. There is no judicial elaboration as to the limitations that apply to the scope of the relevant constitutional amendment.

There has only been one notable attempt to discuss the limits of the principle of primacy of EU law and of the transfer of powers to the EU, the dissenting opinion of Judge Erotokritou in the 'bail in' case. The case concerned the imposition of a levy amounting to partial confiscation of all unsecured deposits, i.e. below 100,000 EUR, in the two systemic Cypriot banks. The dissenting judge underlined the significance of ensuring, through judicial review, that any European and national mechanism forming the foundation for the imposition of a bail-in, respects fundamental rights and the rule of law. The case and the dissenting opinion will be 
explored in greater detail in Sect. 2.7.3, drawing parallels with the German Constitutional Court's Honeywell judgment.

1.3.4 As seen in Sect. 1.2, the amended Art. 179(1) provides that '[w]ithout prejudice to the provisions of Art. 1A, the Constitution shall be the supreme law of the Republic'. The Constitution has to give way in case of a conflict with EU law, and that would logically trigger a constitutional amendment. As seen with the EAW saga, the rectification of the incompatibility took years.

\subsection{Democratic Control}

1.4.1-1.4.2 In relation to applicable rules that govern the participation of the national parliament in the EU decision-making processes, in the case of Cyprus, no such rules exist. Moreover, no referendum has ever taken place in relation to the EU nor has there being any discussion about one.

\subsection{The Reasons for, and the Role of, EU Amendments}

1.5.1 As explained in greater detail in Sect. 1.2, on the one hand, the guiding background premise has been the traditional reluctance of the judiciary to approve constitutional amendments; on the other hand, the Supreme Court through its ruling in Constantinou in effect required the introduction of a constitutional amendment that would govern the relationship between EU law and the national constitutional order. The outcome was the introduction of the Fifth Constitutional Amendment that has an overly expansive scope and leaves little, if any, room for the subsequent establishment of specific boundaries for the relationship between EU law and Cypriot constitutional law. By way of an additional point of background information, the approach behind the amendment was modelled on the method of Art. 29(4)(3) of the Irish Constitution (now Art. 29(3)(10)). ${ }^{37}$ The original idea was to ensure the primacy of EU law in one single article of the Constitution that would then function as the point of reference for any incompatibility of EU law with national constitutional law. That is now Art. 1A. Nonetheless, it must be noted that despite the fact that the introduction of an umbrella provision was based on the Irish model, the provisions of the Fifth Constitutional Amendment eventually took a completely different form in terms of methodology and approach. There is instead a

${ }^{37}$ Lycourgos 2010, pp. 104-106. 
nexus of constitutional provisions that were amended in addition to the introduction of the single umbrella provision inserted in the Constitution (Arts. 11, 140, 169, 179).

1.5.2 The Cypriot example has two distinct phases in relation to EU-related constitutional amendments. The first phase, which lasted until 2006, was characterised by the conscious decision not to introduce a constitutional amendment in relation to EU law. The rationale related to the pre-existing caution towards constitutional amendments for reasons having to do with the doctrine of necessity, the protection of the international status of the Republic, political reasons and the complexity of the procedure for constitutional amendments. The second phase is characterised by the introduction of the Fifth Constitutional Amendment that has been extremely open and accommodating for EU law.

In relation to the issue of 'waning constitutionalism' raised in the Questionnaire, such argumentation has not appeared in the Cypriot context as a factor that could influence the decisions during either the first or the second phase. The rationale for both periods has been pragmatic and has reflected the approach that the Supreme Court had adopted at different stages. The shift in the judicial approach in the second phase was influenced by the clear clash between competing supremacies, namely the primacy of EU law and the supremacy of the Constitution. As a result, the judicial reasoning was founded on formal and substantive hierarchy and mirrored considerations relating to functionality and pragmatism.

1.5.3 The symbiosis of the national constitutional order with supranational legal orders that have dense constitutional characteristics is becoming more difficult as the areas of coexistence start to include fields traditionally associated with the state. The need to define and regulate the boundaries between the legal orders is becoming pressing, and the introduction of constitutional amendments represents the most preferable option for two reasons. First, the regulation of the relationship thus stems from the expression of the will of the state that is reflected in the Constitution. This is significant for symbolic and substantive reasons, as it justifies the transfer of powers from the national level to the supranational level by direct reference to the national Constitution. In addition, any amendment would be introduced on the basis of the usually enhanced procedures that require a higher threshold of democratic approval, thus attributing a much-needed element of legitimacy to the relationship between the national and the supranational legal orders. Secondly, the solution of introducing a constitutional amendment is the most functional way to delimit the boundaries, reinforce legal certainty and provide the opportunity to express any reservations that the state decides to apply as to those limits. Such considerations are specifically relevant in relation to the primacy of EU law, fundamental rights and the allocation of competences. 


\section{Constitutional Rights, the Rule of Law and EU Law}

\subsection{The Position of Constitutional Rights and the Rule of Law in the Constitution}

2.1.1 The position of fundamental rights in the Cypriot constitutional system is central both in terms of their provision and effective protection. The 1960 Constitution contains an extensive bill of rights in Part II ('Fundamental Rights and Liberties'), which in terms of content is $\operatorname{similar}^{38}$ to that of the European Convention on Human Rights (ECHR) and, as Kyriacou ${ }^{39}$ and Pikis ${ }^{40}$ rightly observe, the provisions of which in 'certain instances are wider in scope and substance compared to their counterparts found in the [Convention]'. ${ }^{41}$ Moreover, the Constitution by a series of articles guarantees certain social and economic rights $^{42}$ to the individual which are to be exercised within the framework of the public interest and common good. ${ }^{43}$ The relevant provisions are detailed and comprehensive, and the judiciary has been extremely active in ensuring the full protection of these rights.

It can be argued that the level and content of the judicial protection of fundamental rights has been developed in direct connection with the ECHR system, in which Cyprus participated as part of the colony regime even before independence in 1960. The ECHR has been used as a guiding factor for establishing the level of protection and it has become particularly relevant where there has been ambiguity either in the constitutional text ${ }^{44}$ or in the facts of a specific case. Moreover, the Cypriot system has exceeded the standard that the European Court of Human Rights (ECtHR) requires in numerous cases, with the Supreme Court making direct reference to the need to adopt a higher standard of protection. ${ }^{45}$

In relation to general principles of law, this concept is present and active in the Cypriot system of public law, either as an independent source of law or as an auxiliary tool used for supplementing existing constitutional provisions. Such general principles can be directly derived from the common law that provides the early foundation for the Cypriot legal system (due process, audi alteram partem);

\footnotetext{
38 Kombos and Pantazi 2012.

39 Kyriacou 2010, p. 2.

${ }^{40}$ Pikis 2006, p. 43.

41 Kyriacou 2010, p. 2.

42 Tornaritis 1968, clarifies that Professor Bridel, who assisted in the drafting of the Constitution, recommended the incorporation of the liberty to work, trade and industry, liberty of contract and the right to strike.

43 Tornaritis 1968 , p. 2.

${ }^{44}$ For example, Attorney General v. Afamis, n. 25.

${ }^{45}$ Charalambous and others v. Republic, Joined cases 1480/2011, 11 June 2014; Police $v$. Ekdotiki Eteria [1982] 2 CLR 63; David Scattergood v. Attorney General [2005] 1 CLR 142 (see Sect. 2.3 below).
} 
they are primarily procedural in nature yet with a substantive effect on the essence of the basic right to fair trial. Nonetheless, the influence of such principles has remained limited due to the fact that the Constitution exhaustively covers the rights to fair trial and personal liberty in a combined manner through Arts. 11, 12 and 30.

In terms of general principles not resulting directly from the Constitution, the most notable example is the principle of proportionality. Proportionality has been given an elevated status through the codification of the general principles of administrative law in Art. 52 of Law 158(I)/99. Nonetheless, proportionality already had a constitutional position as an unwritten principle of law and has been referred to by the Supreme Court in the landmark judgment Ibrahim (see Sect. 1.1) as an essential criterion to be met in order for the constitutionally crucial doctrine of necessity to be applicable. The overall effect is that the principle of proportionality is not just a general principle of law with constitutional status, but it also constitutes an integral criterion for the assessment of the foundation of the Constitution post 1964 , that is, the doctrine of necessity.

2.1.2 The Constitution in Art. 33 provides for the conditions under which restrictions can be imposed on rights:

1. Subject to the provisions of this Constitution relating to a state of emergency, the fundamental rights and liberties guaranteed by this Part shall not be subjected to any other limitations or restrictions than those in this Part provided.

2. The provisions of this Part relating to such limitations or restrictions shall be interpreted strictly and shall not be applied for any purpose other than those for which they have been prescribed.

Further considerations pertaining to Art. 33 will be explored in Sect. 2.2.

2.1.3 The Cypriot Constitution makes no express reference to the concept of the rule of law, but this has not stopped the judiciary from positioning the concept at the epicentre of our constitutional law.

The clearest example of the general approach towards the rule of law can be found in the above-mentioned landmark judgment Ibrahim where the Supreme Court introduced the doctrine of necessity. The foundation for the decision was that after the withdrawal of the Turkish-Cypriots and the resignation of the two foreign judges, the administration of justice could not function, which thus directly affected the rights of the individual in a negative way. The consequence of this was to nullify the meaning of the rule of law that was defined as being inherently interlinked with judicial supervision and effective judicial protection, fundamental rights and the principle of legality. This approach, which led to the introduction of the doctrine of necessity, has since permeated the Cypriot legal system.

In terms of justiciability, both parties to legal proceedings and the national courts frequently use the principle of the rule of law, but the principle is not independently justiciable. Rather, the invocation of the rule of law is combined with other legal principles that are content-specific in a manner that is constitutionally precise. The general perception as to the rule of law is that it represents the fundamental 
principle for the legal system and it forms part of all other constitutional principles that are to be construed with the principle of the rule of law in mind.

One such manifestation of the rule of law is access to courts, especially in relation to judicial review proceedings. Article 146 of the Constitution guarantees access to the jurisdiction of the Supreme Court as an administrative court in a liberal and generous way. ${ }^{46}$ Specifically, Art. 146(2) states that '[s]uch a recourse may be made by a person whose any existing legitimate interest, which he has either as a person or by virtue of being a member of a Community, is adversely and directly affected by such decision or act or omission'.

Furthermore, the principle of the rule of law is present in the constitutional provisions that prohibit retroactivity (Art. 24(3) in relation to tax law and Art. 12(1) in relation to criminal law, see Sect. 2.3.2) and that guarantee legal certainty. Articles 3 and 104 require the publication of all laws as an essential requirement for their validity.

\subsection{The Balancing of Fundamental Rights and Economic Freedoms in EU Law}

2.2.1 In Cyprus, the balancing exercise pertaining to the protection of classic constitutional and/or fundamental rights must initially be considered with respect to the application of the doctrine of necessity (as developed in more detail in Sect. 1.1). In Alloupas v. National bank of Greece, ${ }^{47}$ it was held by the majority of the Supreme Court of Cyprus that constitutional rights may only be restricted on the express basis of the Constitution and by applying the 'strictest possible' criteria of necessity (does a state of necessity exist) and of proportionality (are such restrictions proportionate to the necessity). ${ }^{48}$ As seen in Sect. 2.1.1, the principle of proportionality has been granted constitutional status as an 'unwritten principle of law', and it was referred to by the Supreme Court as an 'essential criterion' in the application of the doctrine of necessity. If the Supreme Court initially gave a rather wide interpretation to the principle of proportionality, starting with the Ibrahim case, it did so when the application of the doctrine of necessity 'did not concern the exercise of legislative powers by the executive, or the restriction of fundamental individual rights'. ${ }^{49}$ The Court also gave a narrow interpretation to the principle of proportionality and refused to consider administrative acts of a final nature, decided by an administrative organ out of its own discretion (not deriving from a law) as

\footnotetext{
46 See Kombos 2010b.

47 [1983] 1 CLR 55.

48 Emilianides 2013, p. 47.

49 Ibid., pp. 42-4.
} 
justified on the basis of the doctrine of necessity, ${ }^{50}$ for the reason that administrative acts are not general in nature and are therefore more likely to be arbitrary. As a result, '[a]dministrative acts of a final nature could not themselves be justified on the grounds of the doctrine of necessity; however, administrative acts of a final nature which were based on a law, which was justified on the grounds of the doctrine of necessity, would also be justified' ${ }^{51}$ Thus, it appears that the protection of constitutionally safeguarded fundamental rights in Cyprus has remained largely outside of the scope of the doctrine of necessity, as also noted in Sect. 1.1.2 of the Report.

It was seen in Sect. 2.1 that the Constitution contains a detailed and extensive list of rights, which at times are more extensive than comparable rights under the ECHR, and that in the case of doubt, the interpretation favours the individual over the state. According to Emilianides, the protection of the rule of law is a 'cardinal principle' of the Constitution. ${ }^{52}$ This, combined with the supremacy of the Constitution, means that 'the courts have the power to examine the constitutionality of both laws and action of the administration and that no law, regulation or administrative act may be inconsistent with the Constitution'. ${ }^{53}$ This means that a trial court (i.e. any court other than the Supreme Court) has the power to declare unconstitutional any law which is contrary to the provisions safeguarding individual human rights as set out in the Constitution. This is the result of the mixed character that applies to the system of review of constitutionality in Cyprus after 1964 whereby the examination of claims of unconstitutionality is diffused and decentralised. This also entails that constitutionally safeguarded fundamental rights must be interpreted in favour of the individual protected rather than the state in case of doubt. $^{54}$

As far as restrictions or limitations to constitutionally safeguarded fundamental rights are concerned, it is stated in Art. 33(1) of the Constitution that these can only be contained in express provisions of the Constitution (see Sect. 2.1.2). A careful review of Part II of the Constitution reveals that such restrictions or limitations can also be contained in legislation within the limits of the Constitution itself, ${ }^{55}$ as introduced by the House of Representatives or 'deemed to be part of Cypriot law under Art. 188 of the Constitution' ${ }^{56}$ or deriving from EU law, ${ }^{57}$ subject to the

\footnotetext{
${ }^{50}$ See Mesaritou v. The Cyprus Broadcasting Corporation [1972] 3 CLR 100; Theodorides v. Plousiou [1976] 3 CLR 319.

${ }^{51}$ Emilianides 2013, p. 44.

${ }^{52}$ Ibid., p. 53. See Sect. 1.1.2 of this Report. See also Loizou (2001) (in Greek).

${ }^{53}$ Emilianides 2013, p. 53.

${ }^{54}$ Fina (Cyprus) Ltd v. The Republic [1962] 3 RSCC 26; see Emilianides 2013, p. 146.

${ }^{55}$ E.g. more recently President of the Republic v. House of Representatives [2000] 3 CLR 238 (in Greek).

${ }^{56}$ Police v. Hondrou and Another [1962] 3 RSCC 82.

${ }^{57}$ See Emilianides 2013, p. 146.
} 
general principles inter alia of reasonableness and proportionality. Article 33(2) of the Constitution expressly provides that such restrictions or limitations must be interpreted strictly and cannot be applied 'for any purpose other than those for which they have been prescribed', thereby providing a general framework of necessity and/or proportionality to the restriction/limitation to constitutionally safeguarded fundamental rights. This provision of the Constitution must be read in conjunction with Art. 35 of the Constitution, which casts a vertical duty on the state and its various branches of government (within the limits of their respective competence) to ensure the efficient application of Part II of the Constitution vis-àvis the beneficiaries of these fundamental rights.

Additionally, it should be noted that the fundamental rights safeguarded under the Constitution are minimum rights. Rights may be further protected or new rights may be established through legislation, in which case these are not protected as constitutional rights but as ordinary rights. ${ }^{58}$ This last point may have direct implications for the protection afforded to rights deriving from EU law and their implementation in the national legal order.

While EU law (all provisions) should take precedence over conflicting constitutional provisions as a result of Art. 1A of the Constitution, the use of the EU Charter by the Supreme Court in its case law is far less developed than the (much older) use of the ECHR. This could perhaps also be explained by looking at the overall practice of the supremacy of EU law by the courts in Cyprus, especially by the Supreme Court. It could be said that despite the reference to Art. 1A in Art. 179 of the Constitution and because the Constitution in Cyprus still provides expressly for its own supremacy, considerations of EU law and the exercise of judicial review arising as a result of the application of EU law in Cyprus appear prima facie to be encompassed within the fabric of the Constitution. This may be the subject of some academic debate in Cyprus, ${ }^{59}$ but in judicial and/or practical terms, the overall approach of the Supreme Court can be described as inconsistent and as sometimes ignoring EU law (or even the ECHR) to concentrate merely on the protection of fundamental rights in accordance with express constitutional provisions. ${ }^{60}$

\footnotetext{
${ }^{58}$ Emilianides 2013, p. 146.

${ }^{59}$ Emilianides argues that EU and EC law are considered an integral part of the Constitution, Emilianides 2013, p. 54; contra Kombos \& Pantazi 2012, p. 309: 'the hierarchical rule resulting from Art. 179 does not apply to EU law'; see also Lycourgos 2010, p. 101. For a detailed analysis, see also Laulhé Shaelou 2010a, pp. 133-40 who concludes: 'The legislative objective of removing the potential conflict between EC/EU law and the Constitution appears a priori achieved; it will however no doubt face the judicial scrutiny of the Cypriot courts through cases on the enforcement of Community law rights in Cyprus', p. 139.

${ }^{60}$ Interview with Dr. Demetrios Hadjihambis, former President of the Supreme Court of Cyprus (June 2013-July 2014) and judge at the Supreme Court (1999-2013), 9 January 2015.
} 
Some of the wide-ranging areas where the Ombudsman of Cyprus and equality bodies in Cyprus have pointed out that national law needs to better ensure fundamental freedoms and the principle of non-discrimination arising from EU law include e.g. the right of entry and residence for same-sex partners and/or the third country national spouse of an EU citizen, the free movement of workers, social assistance, and detention or expulsion orders of EU nationals. ${ }^{61}$ The courts in particular would need to revise their role and adopt a more teleological or holistic approach, as legal actions brought before them normally fall within the (narrow) ambit of the judicial control of administrative acts under Art. 146 of the Constitution and do not entail any balancing exercise established within the fabric of the Constitution for the protection of constitutionally safeguarded fundamental rights. ${ }^{62}$

In general, the protection of constitutionally safeguarded fundamental rights in the Cypriot legal order, whether 'classic' fundamental rights, economic or social rights, has always been at the core of the case law of the Cypriot courts, independently of the supremacy of EU law. As such, the balancing of fundamental rights with economic rights can be said to amount to a 'routine' exercise for the Cypriot courts within the fabric of the Constitution, to which EU law 'merely' added one more - albeit fundamental in nature - dimension, thereby increasing the likelihood of constitutional issues arising. Whereas a full and comprehensive review of the balancing exercise between these rights within the fabric of the Constitution would be beyond the scope of this Report and has been explored elsewhere, ${ }^{63}$ drawing general trends could prove useful. The balancing exercise usually involves a strict (but careful and delicate) construction of the restrictions/ limitations to such rights on the basis of Arts. 33 and 35 of the Constitution and/or in accordance with the case law of the ECHR (in the case of a collision of classic rights). ${ }^{64}$ It is also useful to mention that the collision between social rights 'per se', especially within the framework of the freedom of movement that is so central to the case law of the CJEU, and the right to strike, have not arisen as such in the Cypriot legal order. ${ }^{65}$ This could however be an area of potential conflict between the Cypriot and the EU legal orders given the attachment to social rights of the

\footnotetext{
${ }^{61}$ See in particular Trimikliniotis 2013 for a review of recent domestic case law related to these issues, pp. 121-140.

${ }^{62}$ Administrative recourses under Art. 146 fall under the exclusive revisional jurisdiction of the Supreme Court, both first instance and appellate, are strictly limited to the review of the legality of an administrative act, decision or omission, and exclude any review of the case on the merits. See Emilianides 2013, p. 197.

${ }^{63}$ For a detailed review of the collision between classic rights and/or socio-economic and cultural rights, including within these sub-categories of rights, see Kombos and Pantazi 2012, pp. 338-46. For a thorough consideration of the balancing exercise between economic freedoms and fundamental rights in the European public order with an emphasis on Cyprus, see Laulhé Shaelou 2011.

${ }^{64}$ Kombos and Pantazi 2012, p. 344.

${ }^{65}$ Kombos and Pantazi 2012, p. 343.
} 
former ${ }^{66}$ and to free movement of the latter. ${ }^{67}$ It has been suggested that the overall balancing exercise currently taking place in the Cypriot legal order, whereby the Supreme Court 'advances its own perception' in the event that the standard of protection granted under the ECHR is lower, usually in the absence of any meaningful consideration of the case law of the CJEU, may have to change in the future, especially with respect to potential clashes between social rights and free movement. This could result in the 'lowering' or at least 'alteration' of the standard of protection offered to social rights in the Cypriot Constitution, with a special reference to the right to strike. ${ }^{68}$ In the meantime and until such a conflict arises, what could be said is that the test to be satisfied for the protection of social rights 'within the framework of the public interest and common good' could end up in effect being higher than for other constitutionally protected fundamental rights. This would seem to be confirmed by the recent case law of the Supreme Court of Cyprus related to austerity measures put in place in response to the sovereign debt crisis.

For example, the case of Georgos Charalambos and others v. Republic of Cyprus $^{69}$ concerned a number of recourses brought before the Supreme Court by a number of civil servants against the Republic, the Ministry of Finance and the General Auditor, with respect to the law for the special levy on the pensions and gross salaries of officers and employees in the public sector as well as the pensions of retired persons (Law 112(I)/2011 as amended). The case was brought on the basis of Arts. 23, 24, 26, 28 and 146, but not Art. 9 of the Constitution (right to a decent existence and social security) which can be considered as requiring on a case-by-case basis a higher burden of proof to rebut the presumption of constitutionality afforded to legislation (on the basis of proportionality), including apparently in times of economic crisis. With respect to the combined principles of equal treatment and equality in taxation (Arts. 28 and 24 respectively), the Supreme Court confirmed its previous case law by stating that the principle of equality must be balanced with the economic situation and fiscal policy in place at the time, and that the state has the discretion in 'times of extreme economic crisis' to take measures targeting specific groups of the population 'without necessarily violating the principle of equal treatment'. ${ }^{70}$ Adopting a comparative approach and after examining the legal framework put in place in Cyprus with respect to the special levy (including for the private sector), the Supreme Court subsequently ruled that there had been no breach

\footnotetext{
${ }^{66}$ In Apostolides Georghios \& Others v. the Republic of Cyprus through the Ministry of Labour and Social Insurance \& Others [1982] 3 CLR 928, the Supreme Court ruled that social rights are on an equal footing with political rights but that the economic situation and capacity of the country must be taken into account when assessing compliance of a measure with Art. 9 of the Constitution (right to a decent existence and social security); see Kombos and Pantazi 2012, pp. 314-315.

${ }^{67}$ Ibid. See also the analysis of the dissenting opinion of Judge Erotokritou in the case of Myrto Christodoulou in Sect. 2.7.3 of this Report.

${ }^{68}$ Kombos and Pantazi 2012, p. 345.

${ }^{69}$ Cases No. 1480-4/2011, 1591/2011 and 1625/2011, 11 June 2014 (majority decision) (in Greek).

${ }^{70}$ Translation by the author.
} 
of the principle of equal treatment and that the measures put in place ('in coordination with the competent organs of the EU') could not be deemed 'extreme' and thus disproportionate (proportionality was raised with respect to the right to property), given the economic situation in which Cyprus found itself.

This judgment should be contrasted with the case of Maria Koutselini-Ioannidou and others v. The Republic, ${ }^{71}$ with respect to the reduction of pensions of retired civil servants and public officers who have been re-employed in the public sector based on Law 88(I)/2011, which was deemed unconstitutional on the basis of Art. 23 of the Constitution, independently of the current economic climate and/or any obligations as may arise under EU membership and/or the ECHR. In this majority decision, the Supreme Court distinguished this case from the previous one on the basis that pensions are a property right which cannot be limited in the name of the public interest on the basis of Art. 23. In the second judgment in the case, however, Judge Michaelidou referred to the expression of the general concept of public interest, included in Art. 23 under the form of public benefit, and to the need to justify it. ${ }^{72}$

In a wider framework, it should be briefly noted that the right to free movement and residence on the territory of the Republic of Cyprus ${ }^{73}$ arguably holds a strategic place in the Constitution, between the right of the accused and the 'no-exile' rule. It should therefore be regarded as a basic fundamental right in the Cypriot legal order and any restriction/limitation to this right should be interpreted strictly (the grounds are contained in the provision itself). To this consideration could be added the case law on shopping hours within the framework of Art. 25 of the Constitution (the right to work) where there has been an uneasy relationship between working conditions and open and fair competition in the name of the general public interest ${ }^{74}$ including post-EU accession. ${ }^{75}$ It is undeniable, however, that there have been overall some gradual adjustments in the balancing of fundamental rights with economic free movement rights or associated/flanking policies, in the name of EU law and/or in favour of economic freedoms falling within the scope of EU law. ${ }^{76}$ An example of this would be the (unanimous) decision in a reference to the Supreme Court $^{77}$ in relation to the law amending the law on the protection of beaches and transposing the Services Directive, analysed earlier in Sect. 2.1. As

\footnotetext{
${ }^{71}$ Joined Cases No. 740/2011-587/2012, 7 October 2014 (majority decision) (in Greek).

${ }^{72}$ In this respect, see speech by Judge Myron M. Nicolatos.

${ }^{73}$ Article 13 of the Constitution.

${ }^{74}$ See Georgoulla Georgiou et al v. the Police [1999] 2 CLR 616 (in Greek) and Andronikos Vasiliadies Ltd et al v. the Police (2001) 2 CLR 715 (in Greek).

${ }^{75}$ A power struggle involving the various branches of government of the Republic of Cyprus has been ongoing for the past few years, with no ultimate outcome yet, as to who has the power to regulate shopping days/hours and related working conditions, and on what constitutional basis/ principle. Overall it would appear that the economic situation of the island prevails over any consideration of EU law.

${ }^{76}$ Dr. Hadjihambis, interview 9 January 2015.

${ }^{77}$ President of the Republic v. House of Representatives, Reference 2/2013, 9 May 2014 (in Greek).
} 
seen, the national Law gave priority to the owners or operators of a seaside hotel or recreational business in relation to the tender procedure for leasing the relevant part of the beach. The lawyers of the House of Representatives justified this policy by the general public interest as an exception to the selection process, including under Art. 12(3) of the Directive (applicable 'where the number of authorisations available for an activity is limited because of scarcity of natural resources or technical capacity') and on the basis of Art. 25 of the Constitution. These arguments were rejected by the Supreme Court not only on the basis of the Directive's requirement that the licensing system should not be discriminatory and disproportionate, but also on the basis that the principles of free competition, as set out in EU law and in the Directive, should prevail. ${ }^{78}$

On a further point, the Court noted that there was no breach of the principle of legitimate expectations since the House of Representatives, in addition to not meeting the deadline for transposition of the Directive at the end of 2012, had through the amending law extended the existing situation until the end of October 2014 , thereby giving ample time to all concerned to comply. ${ }^{79}$

\subsection{Constitutional Rights, the European Arrest Warrant and EU Criminal Law}

Introduction and constitutional amendments The European Arrest Warrant (EAW) Framework Decision (FD) was implemented in Cyprus by Law No. 133(I)/2004 on the European Arrest Warrant and the Surrender Procedures of Requested Persons, which has since been amended three times. ${ }^{80}$ There were initial difficulties in some Member States with the very idea of surrendering their own nationals based on the principle of mutual recognition, including in Cyprus where 'expelling or extraditing' procedures were interpreted as being expressly limited to aliens under Art. 11(2)(f) of the Constitution. ${ }^{81}$ This difficulty persisted following EU accession and the matter was brought before the full bench of the Supreme Court of Cyprus in November $2005 .{ }^{82}$ The Court had to consider the

\footnotetext{
${ }^{78}$ Ibid., p. 12.

${ }^{79}$ Ibid., p. 14.

${ }^{80}$ Consolidated version available at http://www.cylaw.org/nomoi/enop/non-ind/2004_1_133/full. html (in Greek).

${ }^{81}$ See Attorney General v. Afamis, n. 25. An unofficial translation of Art. 11(2)(f) in force until the 2006 amendment is available in English at http://www.law.uj.edu.pl/ kpk/eaw/other/220_EAW. pdf, p. 170. See also case note by Tsadiras 2007, p. 1516.

${ }^{82}$ Attorney General v. Constantinou [2005] 1 CLR 1356, [2007] 3 CMLR 42; see Tsadiras 2007 and Laulhé Shaelou 2010a, pp. 134-137. See also http://www.supremecourt.gov.cy/Judicial/SC. nsf/All/1F76458C67091E86C2257348004BC6B6?OpenDocument and http://www.law.uj.edu.pl/ $\sim$ kpk/eaw/judicial_decisions/Cyprus_Constitutional_Court.pdf.
} 
implementation of the FD in the national legal order and the compatibility of the implementing law with the Constitution. ${ }^{83}$ The Court took the view that Art. 11 of the Constitution provided an exhaustive list of the reasons why a person could be arrested and it did not provide for the execution of an EAW. ${ }^{84}$ It then reiterated its jurisprudence on the prohibition of the extradition of Cypriot nationals, ${ }^{85}$ referred to the Pupino case ${ }^{86}$ and to the lack of direct effect of the FD, and ruled as a result that it was left to its own discretion to interpret national law in this field in accordance with the FD. On this point, it decided that the implementing law was contrary to Art. 11 of the Constitution, as no provision in the implementing law could be interpreted 'in such a way so as to prevail and to be applied as regards the nationals of the Republic' ${ }^{87}$ This judicial decision triggered (indirectly) a legislative reaction and provided the necessary impetus to proceed with long-awaited amendments to the Constitution to reflect EU membership obligations, including with respect to Art. 11. ${ }^{88}$ Following the 2006 amendment to the Constitution (the Fifth Amendment, see Sect. 1.2), the arrest and detention of a Cypriot national for the purpose of extradition to another EU Member State was made possible, provided that it related to offences committed after Cyprus became an EU Member State on 1 May 2004 (Art. 11(2)(f), sub-para. 1) and that such request was not motivated by grounds such as race, religion, ethnic origin or political opinion (sub-para. 3). ${ }^{89}$

\footnotetext{
${ }^{83}$ For the constitutional implications of this case in the Cypriot legal order, see Sect. 1.2.

${ }^{84}$ Laulhé Shaelou 2010a, p. 136.

${ }^{85}$ Georgiou v. Director of Central Prisons [1991] 1 CLR 814.

${ }^{86}$ Case C-105/03 Pupino [2005] ECR I-05285.

${ }^{87}$ Constantinou, para. 24. Translation by the author.

${ }^{88}$ See Sect. 1.2. See also Laulhé Shaelou 2010a, pp. 137-138, and Gorski \& Hofmanski 2008.

${ }^{89}$ Sub-paragraph (f) of Art. 11(2) was substituted with the following:
}

'(f) the arrest or detention of a person ... or of an alien against whom action is being taken with a view to deportation or extradition or of a national of the Republic with a view to extraditing or surrendering him, subject to the following provisions:

(i) the arrest or detention of a national of the Republic for the purpose of surrendering him under a European arrest warrant is possible solely in relation to events that occurred or acts done subsequent to the date of accession of the Republic to the European Union.

(ii) the arrest or detention of a national of the Republic for the purpose of extraditing or surrendering him pursuant to an international agreement binding the Republic is possible solely in relation to events that occurred or acts done subsequent to the publication of the Fifth Amendment of the Constitution Law of 2006.

(iii) the arrest or detention of any person for the purpose of extraditing or surrendering him pursuant to an international agreement is not possible if the competent body or authority under the law, has substantial grounds for believing that a request for extradition or surrender has been made for the purpose of prosecuting or punishing a person on grounds of his race, religion, ethnic or ethnotic origin, political opinion, or of any legal claims of collective or individual rights in accordance with international law.' 
At the same time, Art. 7 of Law 133(I)/2004 was also amended to provide that a request for the issuing of an EAW for the purpose of criminal prosecution must be accompanied by the written approval of the Attorney General of the Republic of Cyprus (who is responsible for criminal proceedings in the territory of the Republic in accordance with Art. 113(2) of the Constitution). ${ }^{90}$ Following these amendments, the legal framework of the EAW in Cyprus remained prime facie incompatible with the FD, to the extent that it set out additional requirements/limitations to the issuing and execution of an EAW, provided for additional protection of fundamental human rights not expressly provided in the FD and, as such, potentially affected the principle of mutual recognition and/or the rights of suspects and defendants. ${ }^{91}$

In 2013 Cyprus proceeded with a further amendment to its Constitution, allegedly to 'fully comply' with its obligations arising from the EAW FD. 92 The amendment was related to the pending extradition proceedings that were examined by the Supreme Court in Dinos Michailides v. Attorney General. ${ }^{93}$ This case was an appeal and concerned a Cypriot citizen against whom a first EAW had been issued in 2013 by the Greek authorities who requested the surrender for purposes of criminal prosecution for money laundering. It should be noted that the prosecution related to events that took place between 1997 and 2001, and that Art. 11 of the Constitution as amended by the Fifth Constitutional Amendment allowed the extradition of Cypriot citizens only for events that took place after accession to the EU in 2004. Article 11(2) (f) was thus further amended in order to allow the extradition of Cypriot citizens in connection to events that took place at any time, even before accession to the EU. ${ }^{94}$ All

\footnotetext{
${ }^{90}$ Amending law 112(I) of 2006, available at http://www.cylaw.org/nomoi/arith/2006_1_112.pdf (in Greek).

${ }^{91}$ See DG Internal Policies of the Union, Citizens' Rights and Constitutional Affairs (2009) 'Implementation of the European Arrest Warrant and joint investigation teams at EU and national level' available at http://www.eipa.eu/files/EUROPEANARRESTWARRANT.pdf 3, pp. 11-12, p. 14 and pp. 18-19; see also Kapardis 2008, pp. 12-23 and http://www.law.uj.edu.pl/ kpk/eaw/ data/cyprus.html.

92 Seventh Amendment to the Constitution Law 68(I)/2013, available in English at: http://www. olc.gov.cy/olc/olc.nsf/all/DA5878C1FB78D167C2257C16002284F7/\$file/The\%20Seventh\% 20Amendment $\% 20$ of\%20the\%20Constitution\%20Law\%20of\%202013.pdf?openelement.pdf.

${ }^{93}$ Dinos Michailides v. Attorney General, Case 221/13, 2 September 2013.

${ }^{94}$ The sub-paragraph (f) in Art. 11 was replaced as follows:
}

'(f) ... the arrest or detention of an alien against whom action is being taken with a view to deportation or extradition or the detention of a national of the Republic with a view to extraditing or surrendering him pursuant to a European arrest warrant or pursuant to an international treaty binding on the Republic, on condition that such treaty is applied by the other party thereto. However, the arrest or detention of any person for the purpose of extraditing or surrendering him is not possible if the competent body or authority under the law has substantial grounds for believing that a request for extradition or surrender has been made for the purpose of prosecuting or punishing a person on the grounds of his race, religion, nationality, ethnic origin, political opinion, or of any legal claims of collective or individual rights in accordance with international law.' 
sub-paragraphs were deleted and time limitations were removed. ${ }^{95}$ The guarantee of non-discrimination on grounds of race, religion and other grounds was clearly reiterated and now applies to all persons subject to extradition or surrender procedures, whether nationals of the Republic or not, and whether the subjects of a European or an international arrest warrant. This Seventh Amendment to the Constitution with respect to the surrender of Cypriot nationals was welcomed by the Supreme Court of Cyprus in its recent case law as necessary for the Republic to fully abide by its obligations under the FD. ${ }^{96}$

\subsubsection{The Presumption of Innocence}

2.3.1.1 The legal maxim of nullum crimen nulla poena sine lege is a fundamental principle of Cypriot criminal law embodied in Art. 12(1) of the Constitution, which provides that

[n]o person shall be held guilty of any offence on account of any act or omission which did not constitute an offence under the law at the time when it was committed; and no person shall have a heavier punishment imposed on him for an offence other than that expressly provided for it by law at the time when it was committed.

It was on the basis of the principle of the non-retroactivity of criminal law deriving from this provision that the Republic had sought inter alia to limit the scope of application of the EAW in Cyprus to suspected offences committed post EU accession (in the Fifth Amendment). This concern, however, appeared unfounded for procedural law and was accordingly removed with the Seventh Amendment to the Constitution. Article 12(2) of the Constitution also sets out the rule against double penalty (ne bis in idem): 'a person who has been acquitted or convicted of an offence shall not be tried again for the same offence. No person shall be punished twice for the same act or omission except where death ensues from such act or omission'. This is a constitutional right that even precedes the birth of the Republic, without deviations, even in the name of public security. ${ }^{97}$ There is also a guarantee in the Constitution against arbitrary punishment (Art. 12(3)) as well as against general confiscation of property (Art. 12(6)). ${ }^{98}$

The presumption of innocence also features in Art. 12(4) of the Constitution. It provides that 'every person charged with an offence shall be presumed innocent

\footnotetext{
${ }^{95}$ Cyprus had been criticised for having introduced such time restraints. See Christou 2012, p. 63 and fn. 31 in particular.

${ }^{96}$ See Dinos Michailides v. Attorney General of the Republic, Civil Appeal 221/13, 2/9/2013.

${ }^{97}$ Paraskeva 2015, p. 185. In the context of the EAW, see District Court of Larnaka, Case No. 2/ 06, based on Law 133(I)/2004 and concerning the execution of an EAW against Vakhtang Obolashvili, 4 May 2005, where the District Judge refused to execute the EAW against the requested person based on the principle of double jeopardy (developed below).

${ }^{98}$ For a general consideration of the rights of the accused, with respect in particular to Arts. 11 and 12 of the Constitution, see Emilianides 2013, pp. 157-159; see also Paraskeva 2015, pp. 176-220. On the rights of suspects of criminal offences, see also Stefanou 2011.
} 
until proved guilty according to law'. This is a constitutional right without qualification, constitutes a human right and, in the context of procedural law, applies all throughout the process - before, during and until the final conviction of the accused. It is important to note that this right is afforded to all, whether nationals or aliens. It lies entirely in the hands of the judiciary to determine whether a criminal offence has been committed by a person, provided the prosecution can prove so beyond all reasonable doubt. ${ }^{99}$ This means in particular that no public authority can speculate on the guilt of a person before he/she has been convicted by a competent court. Thus, it was held that administrative decisions attributing criminal acts to a person were in violation of the constitutional presumption of innocence and, as such, unconstitutional. ${ }^{100}$ It should also be noted that the presumption of innocence in Cypriot constitutional law also implies that the accused has a right to silence and against self-incrimination. ${ }^{101}$ Exercising these rights, which are ancillary to the presumption of innocence, does not mean admitting guilt. ${ }^{102}$

The absolute protection afforded to the presumption of innocence by the Constitution raises interesting questions in the context of the EAW and mutual recognition, with respect in particular to the authorities involved, the procedure and the nature of the arrest warrant. Following the Seventh Amendment to the Constitution, Art. 11(3) now provides that 'save when and as provided by law in case of a flagrant offence punishable with death or imprisonment', a person can only be arrested under the authority of a reasoned judicial warrant issued according to the formalities prescribed by the law or pursuant to an EAW (the latter reference to the EAW having been added by the Seventh Amendment). The police cannot therefore proceed with the arrest of a person without the issue of a judicial warrant/ EAW and its communication to the relevant authorities of the Republic. The central authority for the issue and execution of EAWs in Cyprus is the Ministry of Justice and Public Order, i.e. an executive organ of the state, although other key actors such as the police force, the Law Office of the Republic and District Judges are also involved in the process. ${ }^{103}$ The competence of the central authorities in other Member States was challenged before the courts in Cyprus in relation to the execution of EAWs, but in vain. The case of Igor Ovakimyan v. Attorney General of the Republic concerned the execution in Cyprus of an EAW issued by the Dutch Central Authority. The Supreme Court upheld the decision of the Limassol District Court to execute the EAW against the appellant and ruled that the Central Authority

\footnotetext{
${ }^{99}$ Rex v. Mentesh 14 CLR 233; Police v. Chrysanthou 15 CLR 50 and Costis Panayi Kefalos v. The Queen 19 CLR 121. For the reversal of the burden of proof in Cyprus law in specific instances, see Paraskeva 2015, pp. 197-198 and in particular fn. 790 and 792.

${ }^{100}$ Kyriakides v. The Republic [1997] 3 CLR 485 (in Greek). See Emilianides 2013, pp. 158-159.

${ }^{101}$ President of the Republic v. House of Representatives [1994] 3 CLR 1 (in Greek). See Emilianides 2013, p. 158; see also Paraskeva 2015, pp. 201-202.

102 Charalambous v. The Republic [1985] 2 CLR 40; Emilianides 2013, p. 158.

${ }^{103}$ See http://www.police.gov.cy/police/police.nsf/All/367B2EB11E7D96B9C2257A1E002E2E17? OpenDocument.
} 
can also be a public prosecutor or other judicial body as determined by the legal system of each state. In the Netherlands, as the Cypriot Supreme Court noted, despite being assigned to the Ministry of Justice, the public prosecution service belonged to the judiciary branch of government. ${ }^{104}$ This was repeated in Eva Karina Andersson v. Attorney General of the Republic in the context of the execution of an EAW from Sweden. ${ }^{105}$ It appears to be in line with the jurisprudence of the ECtHR on the nature of the 'court' as an independent organ from the executive power. ${ }^{106}$ Thus, the essence of the matter seems to be that the EAW must remain in effect a 'judicial decision', ${ }^{107}$ independent from the executive. This does not seem to be exactly the case in Cyprus ${ }^{108}$ or at least was arguably not the case until 2014.

In Cyprus, once a request is transmitted to the Central Authority, it is communicated to the Attorney General who is also not a judicial authority, but an independent officer of the Republic (Arts. 112-114 of the Constitution). The latter is said to perform a 'double-check' to the extent that the police first 'presents the case' and subsequently a draft of the EAW for approval by the Attorney General. This administrative/technical process, prior to the judicial decision being taken, has been criticised in evaluation reports as being at the very least unnecessary and perhaps more seriously in violation of the principle of mutual recognition and/or the spirit of the FD, to the extent in particular that it could constitute an obstacle to a request reaching the District Court in Cyprus. ${ }^{109}$ Furthermore, it should be noted that while the Attorney General performed its double check, the Central Authority would until 2014 scrutinise the EAW in terms of formalities but also substance, with the possibility to request further information or a re-issue of the EAW by the issuing state. It was only following this screening procedure that the Central Authority would proceed with issuing a certificate under Sect. 16(1) of the implementing law and transmit it to the judge who would decide under Sect. 16(2) on the issue of an arrest warrant under the implementing law. As ably noted by Christou, this certificate constituted no guarantee that the EAW would not be 'challenged before the courts', since the Central Authority is not a judicial authority either, thereby begging the question of the real judicial nature of the EAW and of the scope of the principle of mutual recognition in Cyprus.

The role of the Ministry and the Attorney General in the issue/execution of EAWs recently led for the first time to legal issues raised in the case of Mr. Louka in the context of an international arrest warrant from South Africa; the details will be provided in Sect. 3.6. This case entitles one to wonder whether considerations regarding extradition decisions based on political discretion could arise in the

\footnotetext{
104 [2005] 1 CLR 1119.

105 [2008] 1 CLR 1092. See Christou 2012, p. 64 and fn. 50.

${ }^{106}$ Hutchison Reid v. the United Kingdom, no. 50272/99, § 64, ECHR 2003-IV.

${ }^{107}$ See Art. 7(2) of the FD.

${ }^{108}$ See http://www.eipa.eu/files/EUROPEANARRESTWARRANT.pdf, p. 11.

${ }^{109}$ Christou 2012, pp. 64-65.
} 
European context and what safeguards are available in the law to avoid potentially arbitrary results. ${ }^{110}$

It should be said from the outset that the legal framework surrounding international arrest warrants and EAWs certainly differs with respect to their spirit, scope, powers and processes. ${ }^{111}$ With respect to the legal basis of an arrest warrant, the Supreme Court in Scattergood had clarified the judicial character of an arrest warrant issued under the law implementing the EAW FD (as opposed to an arrest warrant issued in other extradition procedures) and that the basis for such arrest warrant was the law implementing the FD (Sects. 3 and 18) and not domestic law. ${ }^{112}$ The Court subsequently stated that a warrant issued on the basis of Art. 16 of the implementing law was a 'preliminary measure' which aimed at ensuring the arrest of the suspected offender, in order to then decide during the course of the procedure "whether the execution of the EAW should be allowed'. ${ }^{113}$ This was quite an ambiguous statement which appears to reveal that the execution of an EAW did not occur 'as if it were issued by the issuing state's own authorities', ${ }^{114}$ as requested by the principle of mutual recognition. More recently, however, and within the context of the amendments to the law implementing the EAW FD in Cyprus, ${ }^{115}$ the Supreme Court, referring to the case law of the ECJ, ${ }^{116}$ clearly stated that there is an 'express obligation' to execute 'every' EAW in accordance with Art. 1(2) of the FD and this obligation is without exception outside of the framework provided in the FD (Arts. 3 and 4) and in the implementing law (Sects. 13 and 14) (see below). ${ }^{117}$

It therefore appeared that, at least until 2014, there were some weaknesses (i.e. extra scrutiny even where it may have favoured the defendant's rights) in the law implementing the EAW FD in Cyprus, with some of them also identified with respect to international arrest warrants. The House of Representatives passed two amending laws to the implementing law in 2014, one in early 2014 where

\footnotetext{
${ }^{110}$ For equivalent considerations arising (indirectly) from unsuccessful pleas by the lawyers of Dinos Michailides subject to an EAW issued by the Greek authorities, see Dinos Michailides $v$. Attorney General of the Republic, Civil Appeal 221/13, 2/9/2013.

${ }^{111}$ As noted by the Supreme Court itself in Scattergood v. Attorney General [2005] 1 CLR 142 (in Greek), the EAW procedure is a 'relative' of the extradition procedure under the relevant domestic law but as such, 'does not stop being different, based on another law enacted within the framework of the EU accession' (translation by the author).

112 Ibid.

113 Ibid.

${ }^{114}$ Christou 2012, p. 65.

115 Amending Law 30(I)/2014 was published in the Official Gazette of the Republic on 7 March 2014 and Amending Law 183(I)/2014 on 12 December 2014.

${ }^{116}$ Case C-388/08 PPU Laymann and Pustovarov [2008] ECR I-08993, para. 51; Case C-261/09 Mantello [2010] ECR I-11477, para. 36.

117 Civil Appeal No 184/2014, Hadwen James v. Attorney General, 17 July 2014; for a more flexible approach, see Civil Appeal No. 41/14, Attorney General v. Mrukwa, 5 March 2014; see also n. 127 below.
} 
significant amendments were made to a number of provisions of the law, ${ }^{118}$ and again in late 2014 where one additional amendment was made to the rights of the person subject to the EAW. ${ }^{119}$ Through the first amending law, the power given to the Central Authority (CA) to scrutinise the EAW and issue a certificate of compliance under Art. 16 para. 1 was revoked, and the CA was merely left with the obligation to ensure the arrest of the person subject to the EAW; there is only mention of the power of the judge to proceed with the issue of a temporary arrest warrant in the case of an emergency and on the basis of an EAW or before the issue or the transmission of an EAW, following receipt of such a request through EUROPOL or otherwise (new para. 2). The detention time under the temporary arrest warrant was also extended from three to eight days (Art. 16(3)). Amending Law 30(I)/2014 also removed the reference to 'criminal proceedings' in Sect. 3 of the implementing law, thereby arguably enhancing judicial pre-trial and procedural powers.

The above changes appear to reconcile the implementing law with the spirit and provisions of the FD as well as the principle of mutual recognition. It remains, however, to be seen what the impact of the amendments to Sect. 16 of the implementing law will mean in terms of safeguards, including for the respect of the rights of suspects, the protection of the presumption of innocence and of other fundamental human rights/principles embodied in procedural guarantees. In addition to constitutional safeguards in each country, the protection of fundamental rights is also part of the principle of mutual recognition itself, ${ }^{120}$ thereby arguably implying the exercise of a certain level of control by the competent authorities. ${ }^{121}$ It should not mean, however, that the protection of fundamental rights can constitute an autonomous ground of refusal to execute an EAW. This was confirmed recently by the Supreme Court of Cyprus with respect to the EU Charter, in the case of James Hadwen, ${ }^{122}$ with the Court noting that such arguments do not 'fit' within the 'specific procedure' of the execution of EAWs by District Courts (which the Court classified as sui generis). ${ }^{123}$

2.3.1.2 Until at least 2014, however, the authorities in Cyprus, and in particular the District Judges, would not 'automatically authorise extradition with minimum formality and no consideration of evidence' (cf. the Questionnaire). The courts

\footnotetext{
${ }^{118}$ Law 30(I)/2014, 7.3.2014.

${ }^{119}$ Law 183(I)/2014, 12.12.2014.

${ }^{120}$ For Cyprus, see Sect. 2(2) of the implementing law: 'The application of the provisions of the present Law cannot result in the violation of the obligation of respect of the fundamental rights and principles, in accordance with Art. 6 TEU. In any case, the requested person shall not be transferred to a country where he/she would be at serious risk of being subjected to the death penalty or subjected to torture or other inhuman or humiliating or treatment' (translation by the author).

${ }^{121}$ Christou et al. 2009, p. 113.

${ }^{122}$ See n. 117 above.

${ }^{123}$ Ibid.; see also Dinos. Michailides v. Attorney General, Civil Appeal No. 221/13, 2 September 2013.
} 
proceeded with the review of pre-trial evidence to determine in particular the seriousness of the offence, ${ }^{124}$ the time frame and the situation of the person, inter alia whether the person subject to the EAW was more 'at risk' if extradited to the issuing country rather than remaining under arrest and/or in detention in Cyprus. Overall, the courts proceeded on the assumption that there was 'reasonable suspicion' against the suspected person as evidenced by the EAW, which, however, had to be investigated and determined by the District Judge, with a view to arresting and/or detaining the person subject to the EAW. This is quite clearly expressed in the implementing law where it transpires that even after a suspected person is brought before the District Judge, extradition is still only a 'possibility' (Sect. 17 (1)) whereas his/her detention needs to be decided by the judge (Sect. 18(1)). Most of the time, however, an EAW is issued and/or executed, ${ }^{125}$ with one commentator noting with respect to the role of the judge that judges need to 'be moved' by the parties, which is a characteristic of the common law tradition, as opposed to the civil law system where the role of the judge is more inquisitorial. ${ }^{126}$ The Supreme Court of Cyprus has, however, recently expressed in rather strict terms the obligation on the District Courts to proceed with the execution of EAWs and appears to have framed the protection of fundamental rights (exclusively) within procedural guarantees as provided in the FD and the implementing law subject to a proportionality test, thereby potentially adopting a stricter reading than some District Judges on a case-by-case basis. ${ }^{127}$

${ }^{124}$ See e.g. Civil Appeal, Panayiotis Philippou (no. 2) [2009] 1 CLR 693.

125 The latest public statistics available date back from 2010 when 34 EAWs were issued to Cyprus. The statistics of the Ministry of Justice do not specify how many EAWs were actually executed. The annual report only mentions that these EAWs were transmitted to the judicial authorities of the Republic for execution. It then states under the title 'transfer of sentenced persons' that 13 requests were received by the Ministry, out of which 11 culminated in extradition from or to Cyprus; see http://www.mjpo.gov.cy/mjpo/MJPO.nsf/All/88FC4FA80EAFB52A C22579BC003005DE/\$file/etisia\%202010\%20-\%20final.pdf, p. 37.

${ }^{126}$ Christou 2012, p. 66.

127 This does or does not benefit the person subject to the EAW. In James Hadwen (see n. 117 above), the Supreme Court acting as an appeal court, upheld the findings of the trial court to the extent that it had allowed a request for adjournment in order to call an expert witness from Malta to testify that the offence for which he was arrested was time-barred but refused to grant a second adjournment, noting that the execution of an EAW must occur within a strict time frame. The fact that in the application of Sect. 15(2) of the implementing law, the trial court omitted to hear the appellant was not sufficient to render the decision of the District Court to execute the EAW invalid. In Mrukwa (see n. 117 above), the District Judge had refused to execute an EAW issued by the Polish authorities on the basis of delays in justice both in Poland and in Cyprus, and lack of justification, and referred to Sects. 2(2) and 4(1)(f) and/or (g) of the implementing law. In the appeal case, the Supreme Court upheld the decision of the trial court and confirmed that even though the implementing law does not provide for the refusal to execute an EAW on the basis of the timely administration of justice, account should be taken of Sect. 2(2) of the implementing law (and not of the Constitution, as stated by the District Court) which, in conjunction with Art. 6 TEU and the principle of mutual recognition, should ensure the protection of fundamental rights by the authorities of the issuing Member State. 


\subsubsection{Nullum crimen, nulla poena sine lege}

2.3.2.1 The legal maxim of nullum crimen nulla poena sine lege was already discussed in Sect. 2.3.1.1 above in the context of constitutional rights. ${ }^{128}$ It was also said that there is an express human right ground to reject requests for surrender of suspects in the implementing law, the scope of which, however, remains unclear. In line with the FD, the implementing law also includes a list of 32 offences in Sect. 12 (2) which do not require the double criminality principle to be satisfied, provided that the offences are punishable by a custodial sentence or detention order of a maximum period of at least three years in the law of the issuing state (verbatim transposition of Art. 2(2) of the FD). This list remains unamended to date and the section has been described as helping to serve 'substantial justice' by preventing suspects from escaping from justice on procedural grounds. ${ }^{129}$ Despite controversies deriving from the abolition of double criminality, it has been seen as creating a 'better balance between private individuals and national interest in enforcing the law'. ${ }^{130}$

The above provision must be read in conjunction with Sect. 13 of the implementing law where the grounds for mandatory non-execution of an EAW are set out, including some not expressly provided in Art. 3 of the FD (amnesty, ne bis in idem, and lack of criminal responsibility due to age). ${ }^{131}$ It is worth noting that Sect.13 of the implementing law was amended in 2014, but only with respect to the phrasing of sub-para. (d) which reflects Art. 11(2)(f) of the Constitution sub-para. 3, as amended. The two other grounds remain unaffected, namely that the Republic will refuse to execute the EAW in two situations. First, if a person subject to an EAW for the execution of a custodial sentence or detention order is a Cypriot citizen, the Republic will execute the sentence or detention order according to its own criminal laws. Secondly, if a person subject to an EAW for his/her prosecution is a Cypriot citizen, the Republic will not execute the request unless it is assured that after being heard, the person will be transferred to the Republic to serve his/her custodial sentence or execution order passed against him/her in the issuing Member State. These two additional grounds for the mandatory non-execution of an EAW appear to defeat the very purpose of the FD and of mutual recognition and sit rather uneasily with the amended version of Art. 11(2)(f) of the Constitution.

Mention should also be made of the optional grounds for non-execution of an EAW as set out in Art. 4 of the Framework Decision. The implementing law in Cyprus does not reproduce Art. 4(1) of the FD, which provides for the possibility to lift the requirement of double criminality for acts falling outside the list set in Art. 2(2) and within the ambit of Art. 2(4) of the FD. All other optional grounds have been implemented in the Cypriot law (Sect. 14). Given the human rights guarantees present in the implementing law, the perhaps intentional omission of Art. 4(1) FD may appear

\footnotetext{
${ }^{128}$ See also Christou et al. 2009, p. 114.

${ }^{129}$ Dr. Demetrios Hadjihambis, 9 January 2015.

${ }^{130}$ Ibid.

${ }^{131}$ Stefanou and Kapardis 2006, p. 264.
} 
regrettable in terms of substantive justice and mutual recognition. It actually appears that even if an act falls within the ambit of Sect. 12(2) of the implementing law, for which the requirement of double criminality is lifted, the execution of the EAW can still fail on the basis of mandatory (or not) grounds for non-execution, ${ }^{132}$ which provide specific procedural guarantees and/or, as a last resort, on the basis of the general clause for the protection of fundamental human rights in Sect. 2(2) of the implementing law. ${ }^{133}$ In this respect, it should also be noted that in 2014, Sect. 14 of the implementing law was amended by Law 30(I)/2014 to the effect that sub-sections 2, 3 and 4 were added, thereby reinforcing the discretion of the judicial authorities to refuse the execution of an EAW in several additional instances involving the protection of human rights embodied in procedural guarantees. ${ }^{134}$

\subsubsection{Fair Trial and In Absentia Judgments}

2.3.3.1 Article 30(1) of the Constitution provides that '[n]o person shall be denied access to the court assigned to him by or under this Constitution'. The right of access to the courts is however not an absolute right and is subject to reasonable restrictions, such as time limitations. ${ }^{135}$ Article 30(2) then provides that '[i]n the determination of his civil rights and obligations or of any criminal charge against him, every person is entitled to a fair and public hearing within a reasonable time by an independent, impartial and competent court established by law'. Again, this can be subject to restrictions. ${ }^{136}$ Finally, Art. 30(3) combined with Art. 12(5) of the Constitution set out the minimum rights of litigants, including in criminal proceedings and in line with Art. 6(3) ECHR. Thus, every person has the right to (i) be informed of the reasons why he/she is required to appear before the court; (ii) to present his/her case before the court and to have sufficient time necessary for its preparation; (iii) to adduce or cause to be adduced his/her evidence and to examine witnesses according to law; (iv) to have a lawyer of his/her own choice and to have free legal assistance where the interests of justice so require and as provided by law; and (v) to have the free assistance of an interpreter if he/she cannot understand or

${ }^{132}$ Such grounds seem to be used within reason; see e.g. Civil Appeal, Panayiotis Philippou (no. 2) [2009] 1 CLR 693.

${ }^{133}$ In Obolashvili, the District Judge, after refusing to execute an EAW on the grounds of the principle of double jeopardy (Sect. 13(b) of the implementing law), also clearly stated that in any case, a person would not be surrendered if his/her human rights were violated as protected under Sect. 2(2) of the same law. In this case, the length of time since the alleged offence was found by the District Judge to be unacceptable and sufficient in itself to refuse the execution of the EAW. See also Christou 2012, p. 68. Trial court decisions should however be contrasted with judgments delivered by the Supreme Court in its appeal capacity (see Sect. 2.3.1 and n. 97 above).

${ }^{134}$ For a pre-2014 review of procedural guarantees, see Christou 2012, pp. 71-77.

${ }^{135}$ See Emilianides 2013, p. 171.

${ }^{136}$ Ibid., p. 172. 
speak the language used in court. These minimum requirements are deemed to constitute 'fundamental elements of a fair trial' and any deviation therefrom would be in violation of the latter principle and invalidate the proceedings. ${ }^{137}$

Article 12(5)(c) of the Constitution provides in particular that every person charged with an offence has the right to "to defend himself in person or through a lawyer ...'. If it is possible in civil proceedings to have a judgment in absentia provided all minimum rights to a fair trial have been allegedly duly respected, ${ }^{138}$ this does not appear to be the case in criminal proceedings. ${ }^{139}$ For serious offences in particular, the presence of the accused at the trial is required, given the nature of the burden of proof in criminal proceedings and the right to self-representation and participation in the proceedings guaranteed in the Constitution. ${ }^{140}$ As a matter of public order, the presence of the lawyer of the person charged does not discharge the authorities from their obligation to ensure that the accused is present at the trial, at least at first instance, unless that person has fled the country or has waived the relevant rights. ${ }^{141}$

Despite the exceptional nature of judgments in absentia in the Cypriot legal order, legislation was enacted in 2014 in Cyprus to implement the relevant provisions of the EAW FD, as amended by the FD 2009/299/JHA of 26 February 2009, reproducing verbatim the amendments, thereby enhancing the procedural rights of

\footnotetext{
${ }^{137}$ Ibid., pp. 173-174.

${ }^{138}$ See Apostolides v. Orams, Case No. 9968/04, 9 November 2004, where Mr. Apostolides obtained a judgment by default of appearance in the Nicosia District Court against Mr. and Mrs. Orams, British citizens who had purchased his property in the area not under the effective control of the Republic of Cyprus. On 19 April 2005, a second judgment was delivered by the District Court refusing to set aside the earlier judgment on the ground that there was no valid defence to the claim (the court set aside appearance) - a judgment later upheld by the Supreme Court (Apostolides v. Orams [2006] 1 CLR 1402). Those judgments were then registered in, and declared enforceable by, the Queen's Bench Division of the High Court of England pursuant to the Brussels Regulation (Orders made by Master Eyre, 21 October 2005) and successfully challenged by the Orams before the High Court Judge pursuant to Art. 43 of the Brussels Regulation (Orams $v$. Apostolides (QB) [2007] 1 WLR 241). Mr. Apostolides appealed under Art. 44 of the Brussels Regulation before the Court of Appeal of England and Wales, which decided to stay the proceedings and refer five questions pertaining also to the right of the defence, service of documents and public order as grounds for refusal of enforcement of judgments to the ECJ (Case C-420/07 Apostolides [2009] ECR I-03571). For a detailed analysis of the judgment of the ECJ in this case, see S. Laulhé Shaelou 2011, pp. 342-356.

${ }^{139}$ See Report by the European Committee on Crime Problems (CDPC), Council of Europe, writing about judgments in absentia in Cyprus that 'it is not possible except in the case of specified very minor offences for which the accused requests to be permitted to be represented only by his counsel (section 45 of the Criminal Procedure Code) or if summons is proved to have been served on him and he fails to appear in which case the Court may hear the case in his absence (section 89 of the Criminal Procedure Code)', available at http://www.coe.int/t/dghl/standardsetting/pc-oc/ PCOC_documents/Documents\%202013/PC-OC\%20(2013)\%201\%20Summary\%20and\%20Com pilation $\% 20$ of\%20Replies $\% 20$ Quest $\% 20$ judgements\%20in\%20absentia\%20and\%20the $\% 20$ poss ibility $\% 20$ of $\% 20$ retrial.pdf.

${ }^{140}$ See also Sect. 63 of the Criminal Procedure Code, Chapter 155 of the laws of Cyprus.

${ }^{141}$ Paraskeva 2015, p. 212.
} 
persons and fostering the application of the principle of mutual recognition to decisions rendered in the absence of the person concerned at the trial. The courts are now under an obligation (as opposed to this being within their discretion before) to fill in Annex A reproduced from the amending FD. The new legal framework has been perceived positively by the Cypriot courts as giving them additional discretionary grounds to refuse the execution of an EAW (even if no judgments seem to have been issued in absentia so far). ${ }^{142}$

\subsubsection{The Right to a Fair Trial - Practical Challenges Regarding a Trial Abroad}

2.3.4.1-2.3.4.2 As previously noted, judges in Cyprus try to ensure that EAWs are executed. ${ }^{143}$ Beyond the legal framework as developed above, no further information is available on the assistance which Cyprus extends to its own nationals in extradition procedures. Generally and in terms of issuing EAWs, there have been cases where persons requested under an EAW issued by the Cypriot authorities and executed in another Member State have been subsequently cleared of charges by the courts in Cyprus. ${ }^{144}$ There have also been cases where EU nationals extradited to Cyprus under an EAW have been found guilty by the Cypriot courts and transferred back to their country to serve their sentence. ${ }^{145}$ Cyprus, however, remains a place for fugitives to hide in the areas not under the effective control of its government, where the application of EU law is suspended, thereby avoiding EAWs issued by Cypriot or other Member States' authorities. ${ }^{146}$ There are, however, some (rare) examples of surrender of a requested persons under an EAW in connection with the illegal purchase of property in the occupied areas of the Republic of Cyprus, which falls under the category of 'fraud', ${ }^{147}$ forming part of the 32 offences for which the requirement of double criminality has been lifted. On this basis, the UK surrendered a requested person under an EAW to the Cypriot authorities in accordance with the principle of mutual recognition and despite not having an equivalent offence under UK law. ${ }^{148}$

\footnotetext{
${ }^{142}$ See e.g. John Constandinides v. Attorney General, Civil Appeal No. 347/2014, 5 March 2015 (in Greek).

${ }^{143}$ See Christou et al. 2009, p. 113.

${ }^{144}$ See also http://gmadvocates.com/cases/cypriot-businessman-brought-cyprus-under-europeanarrest-warrant-found-be-innocent-charges.

145 http://www.fairtrials.org/cases/michael-binnington-and-luke-atkinson/.

146 http://www.bbc.com/news/uk-19485421. For a detailed legal analysis of the application of EU law in Cyprus, including in relation to the areas not under the effective control of the government, see Laulhé Shaelou 2010a.

${ }^{147}$ See http://www.mfa.gov.cy/mfa/embassies/embassy_stockholm.nsf/ecsw19_en/ecsw19_en? OpenDocument.

${ }^{148} \mathrm{See}$ http://www.chroniclelive.co.uk/news/local-news/former-north-east-nightclub-owner-136 3996; see also Christou 2012, pp. 61-62.
} 


\subsubsection{The Right to Effective Judicial Protection}

2.3.5.1-2.3.5.4 There are mechanisms available in the Cypriot legal order that guarantee access to justice for individuals, such as the principle that time does not start running until full knowledge of the facts has been obtained. In administrative cases, if the Supreme Court has to decide on a matter of facts, it hears evidence first, including from other jurisdictions if necessary. The principle of mutual recognition is based on the mutual recognition of foreign law/judgments; this principle existed in Cyprus before it was applied in an EU context to civil and criminal matters, as Cyprus is a mixed legal system. ${ }^{149}$ As such, the conception of the role of the courts in Cyprus has not really changed and remains, in the context of mutual recognition, mainly concerned with a review of coercive actions by the executive and the justification by the state for its actions. ${ }^{150}$ In a wider framework, the courts in Cyprus may be criticised for privileging formalities over substance. The Apostolides v. Orams case is probably an example of extreme formalism through a literal interpretation of the meaning of losing a case 'by default' (lack of appearance) rather than on the merits, thereby taking the right to appear to the extreme. ${ }^{151}$

\subsection{The EU Data Retention Directive}

2.4.1 The implementation of the Data Retention Directive raised serious constitutional problems in Cyprus and resulted in the Sixth Constitutional Amendment (Law 51 (I)/2010 of 4 June 2010) after a decision of the Supreme Court in Alexandrou (see below). The effect was the amendment of Art. 17(2) of the Constitution that provided for the limitations available for Art. 17(1). Article 17(1) states that '[e]very person has the right to respect for, and to the secrecy of, his correspondence and other communication if such other communication is made through means not prohibited by law'. The new provision of Art. 17(2) allows interference with the aforementioned right through data retention on the basis of a judicial order that relates to the investigation of serious crimes carrying a prison sentence of five years or more. That amendment remains in full force today despite the decision of the CJEU in Digital Rights Ireland and Seitlinger and Others. ${ }^{152}$

Originally, the Republic implemented the Directive with the Law 183(I)/2007 (as amended) that introduced a system for data retention along the lines the Directive requires. However, in terms of scope, the Law applied for any crime that is defined in Sect. 2(1) as 'a felony' either by the Criminal Code or any other

\footnotetext{
${ }^{149}$ See Hatzimihail 2013.

${ }^{150}$ Interview with Dr. Demetrios Hadjihambis, 9 January 2015.

151 Ibid.

152 Joined cases C-293/12 and 594/12 Digital Rights Ireland and Seitlinger and Others [2014] ECLI:EU:C:2014:238.
} 
legislation and/or which carries a maximum prison sentence of five years. Therefore, the Cypriot approach opted for the widest possible definition of serious crime, in order to resolve long-lasting problems relating to the law of evidence and to the empowerment of the police to effectively combat crime in general.

The constitutionality of Law 183(I)/2007 was examined by the Supreme Court in the case of Alexandrou ${ }^{153}$ that concerned the criminal investigation and prosecution of an individual. The Supreme Court assessed whether to grant leave for certiorari in relation to an ex parte order of a first instance court that permitted the use of the data retention system. The reasoning of the Supreme Court needs to be examined carefully because the decision in Alexandrou is often wrongly cited as an example of national reaction to the Directive's approach.

In reality, the Court disassociated the implementation of the Directive from Law 183(I)/2007 despite the fact that the preamble of the legislation expressly stated implementation of the Directive as its intention. The consequence of that disassociation was that the relevant Law was a national measure that had no connection with EU law, and thus could not benefit from the protective scope of Art. 1A of the Constitution. This reasoning of the Supreme Court was formed by relying on the ECJ ruling in Ireland v. Parliament and Council, ${ }^{154}$ from which it deduced that since the Directive was adopted on the correct legal basis (Art. 95 EC that provides for harmonising measures for the common market), then as a corollary the Directive has as its only purpose exactly that. Therefore, the Supreme Court construed the ECJ ruling as limiting the scope of application of the Directive only to matters relating to the legal basis upon which the adoption of the Directive was based. Criminal law and the effective combating of crime were outside the scope of the Directive and therefore the relevant national legislation was disconnected from the Directive. Moreover, it must be noted that the Supreme Court did not examine the provisions of the Directive per se, as that was held to be unnecessary since the ECJ had already examined the purpose of the Directive. In addition, the Supreme Court did not consider whether it was necessary to submit a preliminary reference. The outcome of the preceding reasoning was to approach the relevant law as purely domestic in content and, as such, as unconstitutional and in conflict with Art. 17 (1) of the Constitution.

The judgment paved the way for the Sixth Constitutional Amendment. It must be noted that the constitutional amendment cannot on its own regulate the area in full and hence a legislative act was required in order to specify the scope and manner of application of what the amendment permitted. The only legislation in force that practically enables access to electronic data remains Law 183(I)/2007 that has as its stated aim the implementation of the Directive. Therefore, the retention of data became a domestic issue and policy engraved in the Constitution, but its application is governed by legislation intended to implement the Directive. Moreover, that legislation was held by the Supreme Court to be going beyond the proper scope of

${ }^{153}$ Alexandrou [2010] 1 CLR 17.

${ }^{154}$ Case C-301/06 Ireland v. Parliament and Council [2009] ECR I-00593. 
the Directive that was identified as relating only to market harmonisation. This creates a constitutional paradox since the matter of data retention in its criminal law context seems to have been regulated in Cyprus as a matter of national law and not EU law. This poses the question whether in the absence of the Directive such a course of action would have been followed, and the answer can only be negative.

Before the entry into force of the Constitutional Amendment, a case came before the Supreme Court that touched upon similar matters. In Demetris Siamishis, ${ }^{155}$ the Supreme Court had to examine the constitutionality of the execution of a data retention order that chronologically took place prior the introduction of the Sixth Amendment. The case concerned an appeal from a criminal conviction, and since the appeal could only take into account the law as it stood at the time of the conviction, that conviction was held by the Supreme Court to be unstable as it had taken into account evidence obtained via infringement of the right to privacy. The Court emphasised the connection between the Directive and Law 183(I)/2007, which was considered to be an act implementing the Directive and as such enjoyed the protective status under Art. 1A of the Constitution. It therefore becomes puzzling to compare the preceding statement with the rationale of the decision in Alexandrou, and there is clearly inconsistency as to whether Art. 1A could apply to Law 183(I)/2007. If Demetris Siamishis is good law, then there was no need for amending the Constitution. If Alexandrou is good law, then there should not be any substantially different approach in Demetris Siamishis.

The next important decision that followed the Constitutional Amendment was that in Christos Matsia. ${ }^{156}$ The details of the case are crucial since the case was decided after the aforementioned amendment, but the relevant orders instructing the telecommunications company to make the data retained available to the police were issued prior to the amendment. The Supreme Court in a much lengthier judgment approached the issue of the relation of Law 183(I)/2007 and the proper implementation of the Directive, and reached the same conclusion as in Alexandrou. It was held that the Law exceeded what was required for the implementation of the Directive and was therefore beyond the scope of Art. 1A of the Constitution and, by implication, beyond the relevant supremacy clause that would have shielded Law 183(I)/2007 from a finding of unconstitutionality. The new element in the reasoning of the Supreme Court was that the Court expressly stated that ' $[\mathrm{t}]$ he Law in question exceeds the necessary and proportionate of what the obligations of the Republic entail under EU law'. ${ }^{157}$ That conclusion was solely justified by full citation of paras. 80-85 of the CJEU's decision in Ireland v. Parliament and Council.

The new element in Christos Matsia was the analysis of the importance of the right to privacy and the detailed citation of its development through the case law, with specific reference to the jurisprudence of the ECtHR. However, at no point was there a comparison of the standards applied under pre-existing national

\footnotetext{
155 [2011] 2 CLR 308.

156 [2011] 1 CLR 152.

157 Paragraph 170 of the Judgment (translation by the author).
} 
jurisprudence and under the ECHR with the EU standard, hence no criticism of the Directive was in any way attempted. The key point is that the right to privacy provided the benchmark, and that right did not form part of the argumentation that the ECJ had adopted in Ireland v. Parliament and Council. This was a clear example of a situation in which a preliminary reference should have been submitted to the CJEU with the same content as the subsequent references in Digital Rights Ireland and Seitlinger and Others.

After the entry into force of the Sixth Constitutional Amendment, the Supreme Court consistently held that the data retention system was constitutionally permissible as a matter of national law. From that case law, reference can be made to two judgments that were chronologically subsequent to the ECJ judgment in Digital Rights Ireland and Seitlinger and Others. In the case of Attorney General v. Isaia $^{158}$ and in the case of Sikifantou, ${ }^{159}$ the important issue was the impact of the ECJ decision in Digital Rights Ireland and Seitlinger and Others on the system of data retention that Law 183(I)/2007 introduced. Surprisingly, the Supreme Court in both cases stated that 'the impact of the CJEU's ruling is apparent' since 'Law 183 (I)/2007, according to its preamble, was adopted for the purpose of implementing the Directive on Data Retention'. Nonetheless, the 'apparent' is problematic given the earlier finding in Alexandrou; however, in the case of Attorney General v. Isaia, the Court, by a majority, relied on exactly that statement.

In that case the majority of the Supreme Court held that the annulment of the Directive does not impact on the case before it because Law 183(I)/2007 remains in force as a national measure. The majority decision was extremely brief on the matter and made no mention of the Directive or the ECJ judgment that annulled it. The Court insisted on the existence of a clear distinction between the Directive and Law 183(I)/2007, thus following the rationale and approach of the earlier case law on the matter. It is submitted that such a distinction is formalistic and distorts the legislative intent that was clearly stated in the preamble of Law 183(I)/2007.

The minority judgment (Nathanael and Nicolatos JJ) adopted a rather different approach on the matter. The emphasis was placed on the ECJ decision in Digital Rights Ireland and Seitlinger and Others and on the argumentation that the ECJ applied especially in relation to the principle of proportionality. The conclusion reached stated that Law 183(I)/2007 was founded on the Directive, and that becomes evident from the preamble of the Law. As a result of the annulment of the Directive, the 'legitimising foundation' of the Law disappears and takes with it the totality of the system that enables the police to have access to the retained data. Therefore, the issue arises whether the minority considers Law 183(I)/2007 as being invalid and, if yes, on what basis, given the existence of the Sixth Constitutional Amendment.

To summarise, the approach of the Supreme Court in the area of data retention, either as a matter of EU law or as a matter of national constitutional law, is

${ }^{158}$ Case 402/2012, 07 July 2014.

${ }^{159}$ Case 213/2014, 18 December 2014. 
inconsistent and inherently problematic. The Supreme Court has in effect necessitated a Constitutional Amendment that altered the balance of the content of the right to privacy. The consequence is that the implementation of the Directive has become a matter of national law, irrespective of the stated intention in the preamble of the relevant Law. Therefore, the subsequent annulment of the Directive by the CJEU becomes irrelevant, whereas the whole issue arose out of the need to implement the Directive. This is clearly conceptually cyclical, structurally unsound and constitutionally heretical.

\subsection{Unpublished or Secret Legislation}

2.5.1 Articles 3 and 104 of the Constitution require the publication of all laws as an essential requirement for their validity. There is no case law nor academic comment on this point. The principle of due publication is implicitly also embodied in the principle of good administration.

\subsection{Rights and General Principles of Law in the Context of Market Regulation: Property Rights, Legal Certainty, Non-retroactivity and Proportionality}

2.6.1 As a background to this important part of the Report for Cyprus, the reader should be reminded of the fact that Art. 41 of the 2003 Act of Accession provided that the European Commission had the power to 'adopt measures to facilitate the transition' of the new Member States to the regime of the Common Agricultural Policy. ${ }^{160}$ The European Commission therefore adopted Regulation (EC) No 1972/ $2003^{161}$ (for agricultural products) and Regulation (EC) 60/2004 ${ }^{162}$ (for the sugar market) on this basis, mainly in order to avoid the risk of speculation. Both Regulations required the new Member States to levy charges on holders of surplus stocks on 1 May 2004 for products in free circulation. With respect to the sugar market more specifically, ${ }^{163}$ Art. 6(1) of Regulation No 60/2004 required the European Commission to determine by 31 October 2004 at the latest, for each

\footnotetext{
${ }^{160}$ See Laulhé Shaelou 2010b, pp. 496-497.

${ }^{161}$ Commission Regulation (EC) No 1972/2003 of 10 November 2003 on transitional measures to be adopted in respect of trade in agricultural products on account of the accession of the Czech Republic, Estonia, Cyprus, Latvia, Lithuania, Hungary, Malta, Poland, Slovenia and Slovakia, [2004] OJ 2003 L 293/3.

${ }^{162}$ Commission Regulation (EC) No 60/2004 of 14 January 2004 laying down transitional measures in the sugar sector by reason of the accession of the Czech Republic, Estonia, Cyprus, Latvia, Lithuania, Hungary, Malta, Poland, Slovenia and Slovakia, [2004] OJ L 9/8.

${ }^{163}$ For litigation regarding other agricultural products, see Laulhé Shaelou 2010b pp. 498-500.
} 
Member State, the quantity of sugar as such or in processed products exceeding 'the quantity considered as being normal carry-over stock at 1 May 2004', which needed to be eliminated from the market 'at the expense of the new Member States'. Article 6(2) also provided that Member States had to eliminate such quantities in excess by 30 April 2005, as determined by the Commission. For this purpose, Art. 6(3) of the Regulation required the new Member States to dispose on 1 May 2004 of a system for the identification of traded or produced surplus quantities and to use the system to compel the operators concerned to eliminate quantities at their own expense. The burden of proof was on the operators and, if not satisfied by 30 April 2005, the new Member States were entitled to charge an amount to the operators concerned. With Commission Regulation (EC) No 832/2005, ${ }^{164}$ the European Commission fixed the surplus quantities to be eliminated for each new Member State, taking into consideration activities in the sugar sector of each new Member State before accession (period 1 May 2003-30 April 2004 compared to the average of quantities in the same period for the three previous years). The figure for Cyprus was 40,213 tonnes. The Commission subsequently extended the deadlines with Commission Regulation (EC) No 651/2005. ${ }^{165}$

At the national level, Law 40(1)/2005 was passed to implement the Commission Regulations on the transitional measures in the sector of agricultural goods. The Ministry of Commerce, Industry and Tourism, appointed as the competent authority, had informed the operators of Regulation 60/2004 prior to accession and, upon accession, had requested the relevant information from the operators. In 2005, it set out the surplus quantity for each operator and, in 2006, it proceeded with issuing penalties against the operators concerned on the basis of Art. 5(1) of Law 40(1)/ 2005. ${ }^{166}$ Two administrative actions were therefore taken by the Ministry of Commerce on the basis of Law 40(1)/2005: (i) a decision dated 2 August 2005, requesting the addressees to eliminate the surplus quantities allocated to them by 30 November 2005; and (ii) a decision dated 21 August 2006, imposing a penalty on the operators who did not comply (or only partly complied) with the first decision. As a result, 33 recourses were introduced before the Supreme Court of Cyprus against the 2005 decision, as well as 18 recourses against the 2006 decision, totalling 51 actions which were joined and brought before the Full Chamber of the Supreme Court. In fact, there were actually 52 actions in total, but one of them was judged on the merits on 16 July 2007 by a single judge chamber. ${ }^{167}$ Judge Hadjihambis ruled in this case

\footnotetext{
${ }^{164}$ Commission Regulation (EC) No 832/2005 of 31 May 2005 on the determination of surplus quantities of sugar, isoglucose and fructose for the Czech Republic, Estonia, Cyprus, Latvia, Lithuania, Hungary, Malta, Poland, Slovenia and Slovakia, [2005] OJ L 138/3.

${ }^{165}$ Commission Regulation (EC) No 651/2005 of 28 April 2005 amending Regulation (EC) No 60/2004 laying down transitional measures in the sugar sector by reason of the accession of the Czech Republic, Estonia, Cyprus, Latvia, Lithuania, Hungary, Malta, Poland, Slovenia and Slovakia, [2005] OJ L 108/3.

${ }^{166}$ Laulhé Shaelou 2010b, pp. 496-497.

${ }^{167}$ Morphis Morphy \& Associates Ltd v. RoC through Ministry of Commerce, Case No. 121/2007, 16 July 2007.
} 
that the system put in place for calculating the surplus quantities fell within the scope of Commission Regulation No 60/2004, due to the margin of discretion left to the new Member States to determine the method for such calculation. ${ }^{168}$ The case was appealed $^{169}$ but the Supreme Court decided that this appeal would not be heard until a decision had been issued in the 51 other actions.

During the process of judicial review of administrative actions under Art.146 of the Constitution, an act must be deemed both administrative and executory in order to be reviewed. An act is deemed executory if it is 'determinative in itself of the rights and obligations of a person under the authority of the administration', and the Supreme Court examines whether an act is executory ex proprio motu. ${ }^{170}$ On 13 July 2011, the Supreme Court (Full Chamber) considered the 33 joined actions challenging the 2005 decision $^{171}$ and ruled that the 2005 decision was not executory in view of the 2006 decision which imposed the penalties. It therefore rejected the 33 actions based on preliminary objections. On 21 March 2013, the Supreme Court (Full Chamber) reconvened to consider the 18 recourses for judicial review of the 2006 decision. The Court found (preliminary objections) that the 2005 and 2006 decisions constituted a series of two administrative actions and could be reviewed by the Court in accordance with the Chrikar jurisprudence. It then considered the following grounds for review: (i) retroactivity of taxation prohibited by Art. 24 of the Constitution; (ii) lack of reasonable and due inquiry; (iii) lack of due reasoning; and (iv) lack of competence. The Court ruled that the consideration of the retroactivity of the charge, at the constitutional level, was not 'necessary' in order to establish the ratio of the case and gave no further explanation as to why this was so. The Court then found several reasons why there was a lack of due inquiry on the part of the Republic of Cyprus. For instance, it noted that there was no system specified by law as of 1 May 2004, but on 15 April 2005 (Art. 6 Law 40(I)/105 provided for the retroactive ratification of acts taken during this period). It noted the absence of a legal system duly notifying natural and legal persons of their rights and obligations. Since the surplus quantities had not been established with certainty, the Court found that there was no need to refer to the ECJ and distinguished the facts of the present case from the ones arising in the Balbiino case referred to the ECJ by the Tallinn Administrative Court (Estonia) in the 'sugar saga'. ${ }^{172}$ The Court further ruled that there was a lack of justification in the methods of assessment and identification of surpluses and, finally, that there was lack of competence, since the Minister himself had not authorised the actions.

\footnotetext{
${ }^{168}$ Laulhé Shaelou 2010b, p. 499.

169 The Appeal, scheduled for 12 September 2014 for procedural considerations, was withdrawn. The action was initially based on its compatibility with EU law, the violation of constitutional rights - no retroactivity of taxation, right to trade and non-discrimination, and finally on a review of administrative actions.

${ }^{170}$ Emilianides 2013, p. 197.

${ }^{171}$ Chrikar Trading and others [2011] 3 CLR 541.

${ }^{172}$ Case C-560/07 Balbiino [2009] ECR I-04447. For a review of the relevant litigation in the new Member States, see Albi 2009 and Lazowski 2010.
} 
The Court's decision in the above case was based on the principles of sound administration as established in Law 158(I)/1999 on the General Principles of Administrative Law. As seen in Sect. 2.1, this law is a source of constitutional law as it refers to matters of public law. Some principles like retroactivity and non-discrimination are protected both under the Constitution and this law. But since an Art. 146 recourse is limited by nature to considerations of administrative law and does not extend to a review of constitutionality, it would appear that only the constitutional principles expressly mentioned among the general principles of administrative law are implicit in a review of administrative actions under Art. 146 (namely the protection of legitimate expectations and the principle of proportionality). Even so, it would appear that they will only be considered by the Court when necessary for the establishment of the ratio of the case. This is also true of rights protected expressly under the Constitution, but the Court will not raise constitutional issues out of its own motion. ${ }^{173}$

Thus, contrary to constitutional courts in other new Member States such as Hungary, Estonia and the Czech Republic, ${ }^{174}$ the Supreme Court in Cyprus did not consider any constitutional issues raised in the sugar cases. It restrained itself to a mere control of administrative actions. There is no reference to the EU legal framework either, even if the supremacy of EU law appears to be implicit. To the extent that this decision of the Supreme Court relieves operators from penalties, it could be said to participate in the protection of individual (economic) rights. It is also a clear signal to the public administration in Cyprus that despite EU accession, legal certainty in administrative procedures must prevail and no lowering of national standards is permitted by the Court. ${ }^{175}$ It is argued that this finding could be of utmost significance, especially in the context of the financial crisis (on concerns about the protection of property rights in a dissenting opinion in the 'bail-in' case, see Sect. 2.7.3).

In the meantime, Cyprus requested the annulment of Regulation 651/2005 before the General Court of the EU because it argued that it changed its legal situation under Regulation 60/2004. ${ }^{176}$ The General Court found on the contrary that the amendments with respect to Cyprus were purely procedural and that the act (as amended) had become final vis-à-vis Cyprus since it had not been challenged within the deadline. ${ }^{177}$ The action was therefore found inadmissible. However, this was based on the findings of the General Court that there was no need to be a Member State to challenge generally applicable acts under (then) Art. $230 \mathrm{EC}$, and that it was sufficient to be a legal person. ${ }^{178}$ The General Court had concluded that there was no violation of the principle of effective judicial protection towards

\footnotetext{
${ }^{173}$ Interview with Dr. Demetrios Hadjihambis, 20 August 2014.

${ }^{174}$ See Albi 2009, Lazowski 2010 and Laulhé Shaelou 2010b.

${ }^{175}$ Interview with Dr. Demetrios Hadjihambis, 20 August 2014.

176 Joined Cases T-300/05 and T-316/05 Republic of Cyprus v. Commission [2009] ECR II-00192.

${ }^{177}$ Ibid., paras. 258-260.

${ }^{178}$ Ibid., paras. 241, 245.
} 
Cyprus in this case. ${ }^{179}$ The ECJ however overruled the specific finding of the General Court on the locus standi of new Member States in the Polish case seeking the annulment of Regulation 1972/2003, finding that the General Court had erred in law. ${ }^{180}$ Cyprus did not appeal the decision of the General Court although its arguments with respect to Regulation 651/2005 had not been heard, contrary to Poland for whom Regulation 735/2004 was found to make substantial changes to Regulation 1972/2003 and whose action was deemed admissible, thereby raising the question of effective judicial protection vis-à-vis Cyprus.

\subsection{The ESM Treaty, Austerity Programmes and the Democratic, Rule-of-Law-Based State}

2.7.1-2.7.2 The constitutionality of the Treaty Establishing the European Stability Mechanism (ESM Treaty) has not been directly raised in Cyprus despite the fact that the Supreme Court had to examine the legality of the 'bail-in' that was imposed on Cyprus. Specifically, issues relating to the structure of the financial stability mechanism and its actual funding were not discussed in connection with budget autonomy and responsibility. Moreover, no constitutional amendment was introduced in relation to those matters or Eurobonds and the Banking Union.

2.7.3 Some of the case law regarding the impact of austerity measures on constitutional rights was provided in Sect. 2.2.

A further central case regarding the judicial protection of property rights and judicial review concerned the 'bail-in' measures in 2013. As is explained in Sect. 3.5, the bail-in decision resulted from a political agreement at the Eurogroup level and had the effect of imposing a levy amounting to partial confiscation of all unsecured deposits, that is below 100,000 EUR, in the two systemic Cypriot banks.

The legality of the measures adopted to impose the 'bail-in' were contested in Myrto Christodoulou, ${ }^{181}$ or what is referred to in the rest of the Report as the 'bail in' case. The majority decision, taking an unsatisfactory position, classified the matter as one belonging to the sphere of private law, and therefore the proper course of action was to initiate actions for damage for breach of contract and tort law. Therefore, the issue was not one of administrative law, as it concerned the relationship between depositors and the banks, and the recourse filed under Art. 146 of the Constitution was dismissed. In terms of the civil actions, the criterion to be applied was whether the loss suffered would have been greater if the 'bail-in' had not taken place. This criterion was mentioned eight times in the judgment of the majority. The majority judgment did not examine the EU aspect of the matter nor consider the possibility of sending a preliminary reference.

\footnotetext{
${ }^{179}$ Ibid., paras. 242-247.

${ }^{180}$ Case C-335/09 P Poland v. Commission [2012] ECLI:EU:C:2012:385.

${ }^{181}$ Myrto Christodoulou [2013] 3 CLR 427.
} 
In contrast to that formalistic approach, the dissenting judgment by Judge Erotokritou takes a different and much more preferable approach that is perhaps the most complete attempt in Cyprus to discuss the nature of the principle of primacy of EU law and its relationship with national constitutional law. Judge Erotokritou stated that the matter is one that relates to human rights, as it affects the right to property as protected under Art. 17 of the EU Charter and under Protocol 1 ECHR, as well as under Art. 23 of the Constitution. The adopted approach is so important that it necessitates fuller citations:

Recent events in Europe due to the financial crisis and the measures taken, give the impression that not only international law, but also the European and national law seems to be rewritten. It is therefore imperative in order to safeguard the rights of the parties arising from the TEU, to give the chance to national administrative courts to control not only the legality of the contested acts, but also the compatibility of the various national laws which led to the contested measures with EU law.

In this part, the dissenting judgment raises the point that the situation that is emerging is one that deviates from pre-existing EU law and creates a new set of factors that are different from those upon which the relationship between national law and EU law has been based so far. Therefore, the 'bail-in issue' is rightly approached as an issue exceeding the consensus that pre-existed, thus necessitating the scrutiny of the compatibility of the new EU/international law measures with the rights arising from EU law. Judge Erotokritou continued:

Where conflict is found and there is no ambiguity, Union law is to be applied, as it takes precedence and is directly applicable. Where conflict is found, but the requisite clarity as to the content and validity of the provisions of Union law is not present, then the national court has the power under Art. 267 TFEU to apply with a preliminary question to the CJEU calling either for the interpretation of certain provisions of EU law, e.g. free movement of capital (Art. $63 \mathrm{TEU}$ ), or for a ruling on the validity of specific legal instruments of the EU institutions. With this assistance, the national court may now proceed to examine the compatibility of national law with EU law.

In this part of the approach, Judge Erotokritou focused on the use of the preliminary reference procedure as a useful tool for exercising the national judicial power of scrutiny. In addition, Judge Erotokritou stated:

National sovereignty undoubtedly gives way to the supremacy of European law and rightly so I would say. But it seems that the further erosion of that national sovereignty and the parallel erosion of fundamental rights, often through informal procedures should at some stage be scrutinised by the CJEU, albeit indirectly through Article 267, as to whether it is compatible with the primary law of the European Union.

This is perhaps the centre of gravity of the approach of Judge Erotokritou. The judge adopts a pragmatic approach that accepts the limitation of national sovereignty as a logical consequence of the need to apply the principle of primacy of EU law. This indirectly refers to the nature of the EU system as being founded on the principle of conferred powers that the Member States have voluntarily transferred to the Union. It is respectfully submitted that if this point would have been specifically included in the dissenting opinion, then it would have acquired a more holistic 
theoretical and substantial character in relation to the way that the national constitutional system sees the Union. This would therefore have formed an opportunity for starting to express the inherent reservations as regards the principle of primacy of EU law and for starting to set the limits to the acceptance of the principle.

The next argument is also very interesting, as it identifies the problem that is created by any further unilateral alteration of the equilibrium that relates to the transfer of sovereignty to the EU and to the corresponding application of the principle of primacy of EU law. This becomes especially relevant if the impact of the alteration is directed towards the protection of fundamental rights and has as a result a unilateral and substantial shift in competences. However, this point could have been further explained as having the meaning that any expansion of EU competences at the expense of national sovereignty in a way that structurally affects the constitutional identity cannot be accepted by the national legal order and even by the ECJ.

One cannot avoid making the comparison of the dissenting decision with the decision and the reasoning of the Bundesverfassungsgericht in the Honeywell case. ${ }^{182}$ There it was held that the ultra vires review by the Federal Constitutional Court, namely the striking down of an EU act, can only be considered by the national court if a breach of competences on the part of the European bodies is manifestly in breach of competences and the impugned act led to a structurally significant shift in the structure of competences that is to the detriment of the Member States. A reference to this judgment would have given an essential element of justification to the argument that Judge Erotokritou was making. This would have been useful also because the Judge impliedly followed the reasoning of the German Court by requiring the CJEU to scrutinise the potential erosion of competences, thus placing the responsibility on the CJEU and not solely on the national court. This reflects exactly the inherent idea that the relationship between national constitutional law and EU law is one that both parties have an obligation to safeguard in order for the relationship to remain one of partnership. Judge Erotokritou continued to reinforce exactly the preceding point by stating that:

\begin{abstract}
In the EU legal system, the supremacy of the rule of law and of legal protection, which form a fundamental principle of the European Union and which are inextricably intertwined with the Republic, can not be eliminated through the creation of exemptions from judicial administrative control, each time for various reasons national governments are in trouble and take decisions which violate basic human rights that are derived from the legal order of the European Union and generally from the European acquis communautaire. The legal restrictions imposed by the Constitution on the exercise of state power must be maintained even in critical and difficult conditions such as those that exist today, in order to ensure the supremacy of the rule of law and of the principle of legality.
\end{abstract}

To summarise, the approach is the best and only example of real discussion about the nature of the relationship between national constitutional law and the principle of primacy of EU law in Cyprus. The approach by Judge Erotokritou

${ }^{182}$ BVerfG, Order of 06 July 2010 - 2 BvR 2661/06 - Rn. (1-116). 
contains many important structural and substantive points that reflect the theoretical perspective about the principle of primacy of EU law and which has two dimensions: that of the CJEU and that of the national Constitution. Moreover, Judge Erotokritou places both parties under an obligation to safeguard the delicate equilibrium in order to prevent any unilateral alterations that could create a clash. In doing so, Judge Erotokritou removes the possibility of tensions arising by requiring the national court to first submit a preliminary reference. This is the same approach inherent in Honeywell. The identification of the delicate issue of fundamental rights and the indirect reference to competences through the connection with the erosion of national sovereignty is also in line with the rich jurisprudence of other national constitutional courts.

Nonetheless, the approach of Judge Erotokritou also does not go far enough and does not fully elaborate on all the crucial points that it raised. The lack of any reference to the jurisprudence of other national constitutional courts, including Honeywell, is one such step short of full elaboration.

The last point to be made is that the dissenting opinion was unfortunately not endorsed by the majority. Nonetheless, it is submitted that the fact that views expressed were not endorsed by the majority does not pre-empt the subsequent adoption of the reasoning of Judge Erotokritou as the formula that the Supreme Court can apply to the primacy of EU law. The dissenting judgment exists and can always be used to supplement the already incomplete approach of the Supreme Court on this issue, regardless of the different views of the majority on one specific matter, i.e. bail-in.

\subsection{Judicial Review of EU Measures: Access to Justice and the Standard of Review}

2.8.1-2.8.6 The characteristics of judicial review in the Cypriot legal order have already been addressed elsewhere in this Report. ${ }^{183}$ Overall, standing requirements have been said to be construed broadly by the Supreme Court, thereby 'guaranteeing the procedural access to effective judicial protection'. ${ }^{184}$ As a manifestation of the doctrine of separation of powers, the Supreme Court in Cyprus seems to be responsible for keeping the balance between access to judicial review and the good administration of justice. ${ }^{185}$ This duty appears to extend also to indirect judicial review in the context of preliminary references to the CJEU.

\footnotetext{
${ }^{183}$ See e.g. Sects. 2.1.3, 2.2 and 2.6 above. No statistical data regarding annulment and relevant grounds is available.

${ }^{184}$ Kombos 2010b, pp. 329 and 350.

${ }^{185}$ Ibid., p. 338.
} 
It should be noted in this respect that the Courts Law of 1960, as amended, ${ }^{186}$ used to provide for a right of appeal against decisions of lower courts to refer or not to refer a matter to the CJEU, limited initially (in 2007) to instances where the court ruled on the basis of an application made by one of the parties to the case, and subsequently extended (in 2008) to cases where the courts would decide to refer on their own motion. The authors of the present Report respectively provided at the time an extensive critical analysis of the right to refer or not to refer a matter to the CJEU. ${ }^{187}$ Suffice to note here that following the Cartesio case, ${ }^{188}$ the Law since 2009 provides that no such appeal is possible.

Following the removal of the right to appeal decisions of lower courts to refer or not to refer to the CJEU, it can be said that lower courts are quite free to use the preliminary reference mechanism, including in matters of interpretation and validity of EU legal acts. However, the first preliminary reference to the CJEU from a court other than the Supreme Court only came in 2013 and did not concern matters of validity of EU legal acts. ${ }^{189}$ In the meantime, the lower courts have gradually developed their legal reasoning in terms of dealing with requests from applicants to refer questions of interpretation of EU law to the CJEU, but still too often reject such requests with little justification, resulting in a very low number of preliminary references to the CJEU from such courts (three in total). ${ }^{190}$ As far as the Supreme Court is concerned, only four preliminary references have been made to date. ${ }^{191}$ These four references appear to indicate a steady trend towards the progressive awareness and 'mastering' of the preliminary reference mechanism by the Court. ${ }^{192}$ Suffice to note here that none of these references appears to raise issues of validity of EU legal acts.

Regarding concerns about a gap in judicial review, in the context of the financial crisis measures, it might be worth briefly recalling the concern in the dissenting opinion of Judge Erotokritou (Sect. 2.7.3) that in the intertwined EU legal order 'the rule of law and legal protection can not be eliminated through the creation of exemptions from judicial administrative control, each time for various reasons national governments are in trouble and take decisions which violate basic human rights'.

\footnotetext{
${ }^{186}$ Law 14 of 1960, Sect. 25, new sub-sect. 2A, as amended in 2007, 2008 and 2009.

${ }^{187}$ Laulhé Shaelou 2010b; Kombos 2010b. For a comprehensive, unpublished study see Lycourgos 2014.

${ }^{188}$ Case C-210/06 Cartesio [2008] ECR I-09641.

189 Sotiris (Akis) Papasavvas v. O Philelftheros Dimosia Eteria ltd and others, Nicosia District Court, Case No. 9493/10, 27 March 2013 (in Greek).

${ }^{190}$ Court of Justice of the European Union, Annual report 2013, Luxembourg 2014, pp. 118.

${ }^{191}$ Ibid.

192 Especially Cypra Ltd v. the Republic, Administrative Appeal 78/2009, 5 June 2013 and Alpha Bank Cyprus Ltd v. Si Senh Dau and others, Joined Civil Appeals E23/2013-E29/2013, 13 September 2013 (in Greek). See Laulhé Shaelou 2010b.
} 


\subsection{Other Constitutional Rights and Principles}

2.9.1 There have been no further notable developments in Cyprus.

\subsection{Common Constitutional Traditions}

2.10.1-2.10.2 The influence and impact of the common constitutional traditions on the definition and interpretation of concepts of EU law has been minimal. From the Cypriot perspective, the matter has not been examined by the Supreme Court, but it can be argued that the opportunity to do so was missed in the 'bail-in' case and in relation to social rights that form a distinct and important part of the national Constitution. Reference can be made to the rather unique passage in Art. 9 of the Constitution that states '[e]very person has the right to a decent existence and to social security. A law shall provide for the protection of the workers, assistance to the poor and for a system of social insurance.'

Nonetheless, the content and scope of the preceding provision is rather idiosyncratic and specifically relevant to the Cypriot context, even if a parallel can perhaps be found in the German Basic Law and the fundamental principle of the 'social state'. It would however be difficult to establish the universality of the principle to the required extent that would qualify it as forming part of the common constitutional traditions. The same could apply in relation to various other national constitutional principles to be found in other jurisdictions. The issue can also be assessed through the perspective and the experience of the ECHR on margin of appreciation and European common ground. The key factor is the progression of time and the maturing of a legal principle that is reflected in the growing acceptance and adoption by the majority of the participating legal orders. In practical terms, the highlighting of the centrality of a legal system in the national constitutional order can be useful especially in the context of the preliminary reference procedure.

\subsection{Article 53 of the Charter and the Issue of Stricter Constitutional Standards}

2.11.1 The Cypriot constitutional system places considerable emphasis on the protection of fundamental rights and on the continuation of a fruitful relationship between the national Constitution and the ECHR. This relationship has been very close and can be characterised as an example of harmonious coexistence. The EU dimension of the matter creates de facto and de jure a legal triangle that governs the applicable standard of protection, but in the Cypriot context the issue has never been discussed fully. The prevailing approach, as can be seen in relation to the Data Retention Directive in Sect. 2.4, tends to isolate the EU aspect at least to the point 
where it resolves any clash with the national standards of protection in favour of the EU standard. Methodologically this is achieved by 'nationalising' the issue and by subsequently modifying the national standard; this is an unfortunate and problematic approach and outcome. Some cases where the Cypriot Constitution and the Supreme Court provide a higher standard of protection than the ECHR were noted in Sects. 1.1.2 and 2.1. Additionally, it will be recalled from Sect. 2.7.3 that Judge Erotokritou in a dissenting opinion has expressed concern about the 'erosion of fundamental rights' 'often through informal procedures'.

At the general level, the constitutional triangle of protection must be 'isosceles'. That would reflect the equality of the legal orders, which is a fundamental prerequisite for the symbiosis of legal orders. This argument is reinforced by two considerations. First, the respect for the constitutional identity of each system and secondly, because of the forthcoming accession of the EU to the ECHR system. As a result, the upwards modification of the EU standard that would favour the protection afforded to a fundamental right must be encouraged, as it will be constructive for both the right in question and for the relationship with national courts. The concept of deference is therefore to be reinforced, and the CJEU has shown such willingness in the Omega case. ${ }^{193}$

\subsection{Democratic Debate on Constitutional Rights and Values}

2.12.1-2.12.3 In relation to the democratic element as expressed through the participation in open discussions about EU measures bound to have a substantial impact on national constitutional values, it can be safely argued that in Cyprus no such deliberations took place at any stage in relation to the EAW or the Data Retention Directive. Moreover, when problems arose in those areas, the Supreme Court indirectly facilitated the opening of a democratic dialogue by requiring the introduction of constitutional amendments. This had the effect of creating a new opportunity for the legislature to discuss in full such matters before proceeding with the constitutional amendments, but the character of that discussion has remained the responsibility of the legislature and the executive. Normally in such situations the legislature invites professional bodies and experts to express their opinions, but such discussion is not conducted at the national level and the public remains largely disassociated. The matter is indeed important given the standing restrictions in relation to an action for annulment of an EU act and it also touches upon the legitimacy of the EU system. However, the fact that Member States through their elective representatives participate in the adoption and implementation of such EU acts cannot be ignored. The responsibility remains at the national level, and the creation of a specific procedure could be beneficial in terms of legitimacy, but it is

${ }^{193}$ Case C-36/02 Omega [2004] ECR I-09609. For analysis, see Kombos 2006. 
questionable whether it could be effective and efficient. One such procedural route could be the assessment of legality prior to the entry into force of the EU act, at both the national and EU level. This, however, has to be assessed in relation to the privileged standing status of Member States and to the efficiency of the EU system. Moreover, issues of national procedural autonomy also arise and there is the potential of national constitutional courts engaging in the review of validity of EU acts in the making that would trigger the preliminary reference obligation for national courts of last resort. The other suggested option, recognising the fact that unconstitutionality has been identified in accordance with the domestic system of control of constitutionality as a defence for the Member State in an infringement proceeding, is problematic. This would occur at a later stage of the entry into force of the EU measure and would create differing levels of compliance for Member States, thus affecting the effectiveness of EU law.

\subsection{Experts' Analysis on the Protection of Constitutional Rights in EU Law}

2.13.1-2.13.2 The symbiosis of the different standards of protection is proving problematic, but it is submitted that this has been the situation for decades, as the experience with the Solange jurisprudence ${ }^{194}$ clearly indicates. The matter is nonetheless bound to come to the forefront of the discussion with the accession of the EU to the ECHR system, and it is perhaps crucial to assess the method and rules of accession especially after the recent approach of the CJEU in Opinion 2/2013. ${ }^{195}$ This author acted as co-agent for Cyprus in those proceedings, and it can be argued that the concerns of the CJEU about the relationship between the two systems and the two Courts were evident in both the questionnaire sent to the intervening parties and in the questions that the CJEU raised during the oral stage of the proceedings.

To summarise, the concerns about the different standards of protection are legitimate but are not new; they form part of the history of the constitutional coexistence.

2.13.3 As regards the quality of the reasoning of the CJEU in cases concerning constitutional sensitivities, it is submitted that unfortunately the Cypriot Supreme Court has so far not raised such concerns or issues for that matter. The limited number of preliminary references submitted by Cypriot courts have concerned specific issues that did not relate to deep constitutional concerns.

In terms of the broader issue, it can be argued that the key is in the formulation of the preliminary reference by the national courts. The detailed statement of the national perception and of the relevant applicable jurisprudence can hopefully steer the approach of the CJEU towards a more detailed reasoning. Such examples, albeit

${ }^{194}$ Internationale Handelsgesellschaft mbH $v$ Einfurh- und Vorratstelle für Getreide und Futtermittel [1974] 2 CMLR 540; Wünsche Handelsgesellschaft (Solange II) [1987] 3 CMLR 225. 195 Opinion 2/13 Opinion pursuant to Art. 218(11) TFEU [2014] ECLI:EU:C:2014:2454. 
with varying success, can be found in the preliminary references in Digital Rights Ireland and Seitlinger and Others and in Outright Monetary Transactions $(O M T) .{ }^{196}$ Moreover, the introduction of dissenting judgments would be beneficial for the clarity and completeness of the stated judicial reasoning, but there are strong informal signs that the CJEU is firmly against any such reform.

2.13.4 In the Cypriot context there is an urgent need to re-establish the boundaries between national constitutional law and EU law because the Fifth Constitutional Amendment and the approach of the Supreme Court have created a tight and restricted topos for airing national concerns about the shaping and upholding of constitutional rights and principles.

\section{Constitutional Issues in Global Governance}

\section{1-3.2 Constitutional Rules on International Organisations and the Ratification and Application of Treaties}

The ratification of treaties in Cyprus ${ }^{197}$ and the transfer of powers to international organisations need to be considered within the framework of the status of the Republic of Cyprus in public international law and the rigid nature of its Constitution, as already analysed in detail in Sect. 1.1. One of the peculiar implications for the Republic of Cyprus deriving from its unique constitutional setting relates to its membership in international organisations. It should be noted that almost from the date of its creation up to its accession to the EU (1961-2004), the Republic of Cyprus was a member of the non-aligned movement. Cyprus is also the only EU Member State that is not a member of NATO or of the Partnership for Peace Programme. ${ }^{198}$ The relationship the Republic maintains with international organisations must of course be examined in the light of the de facto division of its territory and in view of the several attempts (including currently ongoing) to find a solution to the Cyprus problem.

The Council of Ministers has the power to conclude any international agreement by virtue of Arts. 50 and 54 of the Constitution. There is a difference between international agreements concluded with a foreign state or an international organisation falling under the scope of Art. 169(1) of the Constitution and relating to 'commercial matters, economic co-operation and motus vivendi', which are concluded under a decision of the Council of Ministers, and any other treaty,

\footnotetext{
${ }^{196}$ See respectively Joined cases C-293/12 and 594/12, n. 152; Case C-62/14 Gauweiler and Others [2015] ECLI:EU:C:2015:400.

${ }^{197}$ For a legal analysis of the reception of international legal agreements in the Cypriot national legal order, see Laulhé Shaelou 2010b, pp. 471-484; see also Laulhé Shaelou 2010a, pp. 130-140.

${ }^{198}$ Emilianides reports that 'a decision of the House of Representatives that the Republic should apply for membership in the Partnership for Peace programme was vetoed by the President of the Republic Demetris Christofias on 2 March 2011', Emilianides 2013, p. 20.
} 
convention or international agreement falling under Art. 169(2) of the Constitution which requires such international agreements to be 'negotiated and signed under a decision of the Council of Ministers' but will 'only be operative and binding on the Republic when approved by a law made by the House of Representatives whereupon it shall be concluded'. In accordance with Art. 169(3) of the Constitution, all such treaties, conventions and agreements have, 'as from their publication in the official Gazette of the Republic, superior force to any municipal law on condition that such treaties, conventions and agreements are applied by the other party thereto'. ${ }^{199}$ Article 170(1) of the Constitution further provides that the Republic of Cyprus 'shall, by agreement on appropriate terms, accord most-favoured-nation treatment to the Kingdom of Greece, the Republic of Turkey and the United Kingdom of Great Britain and Northern Ireland for all agreements whatever their nature might be'. The Treaty of Guarantee also provides in its Art. I that the

\begin{abstract}
Republic of Cyprus undertakes to ensure the maintenance of its independence, territorial integrity and security, as well as respect for its Constitution and undertakes not to participate, in whole or in part, in any political or economic union with any State whatsoever. It accordingly declares prohibited any activity likely to promote, directly or indirectly, either union with any other State or partition of the Island.
\end{abstract}

These provisions of the constitutional framework of the Republic of Cyprus were at the centre of legal debates prior to Cyprus joining the EU. A group of international legal experts concluded that none of these provisions were an obstacle to Cyprus' EU membership. ${ }^{200}$

\title{
3.3-3.5 Democratic Control, Judicial Review and the Social Welfare Dimension
}

As for democratic control by the House of Representatives, it was already noted that most of the time democratic deliberations are non-existent or limited. The Constitution of Cyprus is, however, based on the principle of representative democracy. ${ }^{201}$ Democratic debates within the House of Representatives take place on a regular basis but not systematically (referendums can take place upon a decision of the House of Representatives following a proposal from the Council of Ministers as per the Referendum Law No 286/1989, but are kept for issues of special importance and of public interest). ${ }^{202}$ It was noted for example in the context of the run-up towards Cyprus' EU accession that there was very little or no

\footnotetext{
${ }^{199}$ The role of the Supreme Court with respect in particular to the ECHR has already been developed in this Report.

${ }^{200}$ Emilianides 2013, p. 212. For a pre-accession consideration of other debates surrounding the impact of Cyprus' EU membership on the Constitution, including with respect to conflict of powers and transfer of powers, see Laulhé Shaelou 2010a, pp. 133-134.

${ }^{201}$ For a detailed description and analysis of the system of government in Cyprus including political parties and their role in the House of Representatives as interpreted recently by the Supreme Court, see Emilianides 2013, pp. 65-75.

${ }^{202}$ For a review of the Referendum Law, see Emilianides 2013, pp. 75-76.
} 
democratic debate taking place in the Parliament, as Cyprus's strategy was mainly based on external considerations and concerns. ${ }^{203}$

More recently, however, mention should be made of the more active role currently played by the House of Representatives in the context of the EU/IMF macro-economic adjustment programme for Cyprus ${ }^{204}$ and of its pivotal role during the negotiations leading to the programme. ${ }^{205}$

The lack of judicial activism in respect of the same matter has been noted elsewhere in this Report. ${ }^{206}$

\subsection{Constitutional Rights and Values in Selected Areas of Global Governance}

3.6.1 The constitutional amendment regarding extradition under international/ European arrangements was discussed in the introduction to Sect. 2.3.

The question of what safeguards are available to avoid potentially arbitrary results in the context of an international arrest warrant arose in the case against Mr. Louka, requested by South Africa, signatory to the European Convention on Extradition since 2003, in George Louka v. Minister of Justice and Public Order. ${ }^{207}$ In the first decision, the Supreme Court had to review the (alleged) administrative decision of the Minister to sign the international arrest warrant issued against Mr. Louka. The lower court had considered the discretionary powers of the Minister to sign the said warrant as an 'acte de gouvernement', which meant that it fell beyond the scope of the Court's powers of review of administrative acts under Art. 146 of the Constitution. The recourse before the Supreme Court was therefore rejected. In the second decision, the Supreme Court ruled in final instance on the request for the issue of an order in the form of habeas corpus, as part of the prerogative orders under Art. 155(4) of the Constitution whereby the Court has the exclusive jurisdiction to review the action of a lower court, in order to determine the lawfulness of

\footnotetext{
${ }^{203}$ Laulhé Shaelou 2010a, p. 42.

${ }^{204}$ With respect for example to the legal framework regarding non-performing loans and the protection of the dwelling house.

${ }^{205}$ See Sect. 2.7.3 and Laulhé Shaelou 2013.

${ }^{206}$ See Sect. 2.7.3 for case law related to the bail-in and Sect. 2.2 for the austerity measures put in place in Cyprus as a result of the financial crisis. On 16 March 2013, a first political agreement was reached between the Eurogroup, IMF and the Cypriot authorities which included a one-off stability levy for all resident and non-resident depositors, both insured and uninsured. This political agreement was rejected by the House of Representatives on 19 March 2013. On 25 March 2013, a second political agreement was reached between the Eurogroup and the Cypriot authorities, supported by all euro area Member States and the international lenders on the policy Programme and the loan package associated with it (10bn EUR in total). The political agreement included inter alia bail-in measures for unsecured deposits in the two main Cypriot commercial banks and a resolution programme. The Memorandum of Understanding was signed between the Cypriot authorities, IMF and the European Commission on 26 April 2013. On 30 April 2013, the Programme was endorsed by the House of Representatives.

${ }^{207}$ Case 5965/2013, 16 October 2013 and Case 124/2013, 8 January 2014.
} 
the authority to detain a person-in this case Mr. Louka. ${ }^{208}$ Not surprisingly, the Court decided that in the case of international arrest warrants to be executed under the relevant law in Cyprus, ${ }^{209}$ the ultimate decision remains with the Minister who can exercise his discretion to sign the warrant. The Court characterised this discretionary power as 'political' and 'executive' in nature, intimately linked to the country's international obligations, thereby falling beyond the scope of judicial control which it found had been effectively exhausted in this case, including with respect to the protection of fundamental human rights and in terms of access to justice. Finally, the Court noted that both the courts and the Minister examine the same criteria and therefore the scope of the examination ought to be different, taking a 'political dimension' in the case of the examination by the latter. It is hardly of any comfort to know that the judicial decision on the extradition of a person may ultimately be subject to political considerations independently of the judicial process accompanying the execution of the warrant. Given the role of the Ministry and the Attorney General in the issue/execution of arrest warrants, one is entitled to wonder what safeguards are available in the law to avoid potentially arbitrary results.

In general, in view of the characteristics of the Constitution as developed in this Report, many of them unique, and the lack of prospects for constitutional improvements pending a solution to the Cyprus problem, ${ }^{210}$ it is debatable to what extent Cyprus is equipped to face a process of globalised constitutional governance.

\section{References}

Albi A. (2005) EU Enlargement and the Constitutions of Central and Eastern Europe. Cambridge University Press, Cambridge.

Albi A. (2009) Ironies in human rights protection in the EU: pre-accession conditionality and post-accession conundrums. ELJ 15:46-69.

Besselink L. (2006) The Dutch Constitution, the European Constitution and the Referendum in the Netherlands. In: Albi A., Ziller J. (eds.) The European Constitution and National Constitutions: Ratification and Beyond. Kluwer, The Hague, pp. 149-156.

\footnotetext{
${ }^{208}$ For prerogative orders, see Emilianides 2013, p. 124.

${ }^{209}$ For the applicable legal framework, see http://www.coe.int/t/dghl/standardsetting/pc-oc/ Country_information1_en_files/CYPRUS\%20\%20national\%20procedures\%20for\%20extradition. pdf.

${ }^{210}$ For an attempt to submit a group of international agreements to a referendum in Cyprus (under the auspices of the UN and not within the framework of the Constitution of the Republic of Cyprus), mention should be made of the so-called Annan Plan put to a referendum in 2004 on both sides of the divide, allegedly promoting a comprehensive settlement to the Cyprus problem and creating a new constitutional framework for the country. See http://www.hri.org/docs/annan/. This Plan was rejected by the Greek Cypriot community and endorsed by the Turkish Cypriot community. For a legal analysis of the Plan from the point of view of EU law, see Laulhé Shaelou 2010a, Chap. 6.
} 
Birkinshaw P., Kombos C. (2009) The UK Approach to the Emergence of European Constitutionalism - Repositioning the Debate: Departure from Constitutional Ontology and the Introduction of the Typological Discussion. In: Arnold R. (ed.) The Emergence of European Constitutional Law. Bruylant, Brussels, pp. 35-75.

Christou T., Kousoupi E., Xanthaki H. (2009) Mutual recognition in criminal matters in Cyprus. European Journal of Law Reform 11(1):111 et seq.

Christou T. (2012) The European Arrest Warrant and human rights in the context of the Republic of Cyprus. Cyprus Human Rights Law Review 1(1):57 et seq.

De Smith S.A. (1964) The Commonwealth and its Constitutions. Penguin Books, London.

Emilianides A. (2006) Beyond the Constitution of Cyprus. Sakkoulas, Thessaloniki.

Emilianides A. (2013) Cyprus Constitutional Law. Wolters Kluwer, The Hague.

Evriviades M. (1975) The Legal Dimension of the Cyprus Conflict. Texas International Law Journal 10:227 et seq.

Gorski A., Hofmanski P. (eds.) (2008) The European Arrest Warrant and its implementation in the Member States of the EU. Wydawnictwo C.H. Beck, Warsaw.

Hatzimihail N. (2013) Cyprus as a Mixed Legal System. Journal of Civil Law Studies 6 (1):37-96.

Kapardis A. (2008) The European Arrest Warrant in Cyprus and constitutional concerns. In Gorski A., Hofmanski P. (eds.) (2008) The European Arrest Warrant and its implementation in the Member States of the EU. Wydawnictwo C.H. Beck, Warsaw.

Kombos C. (2006) Fundamental Rights and Fundamental Freedoms: A Symbiosis on the basis of Subsidiarity. EPL 12 (3):433 et seq.

Kombos C. (2010a) The Esoteric Dimension of Constitutional Pluralism. In: Birkinshaw P., Varney M. (eds.) The End of the 1992 Legal Order. Kluwer, Alphen Aan Den Rijn, pp. 291323.

Kombos C. (2010b) The Supreme Court's of Cyprus and the CJEU's Approach to Standing for Judicial Review and to the Preliminary Reference Procedure. EPL 16(3):327-355.

Kombos C. (2015a) The Doctrine of Necessity in Constitutional Law. Sakkoulas, Athens.

Kombos C. (2015b) The Impact of EU Law on Cypriot Public Law. Sakkoulas, Athens.

Kombos C., Arestis G., Kyriakou N. (2015) Human Rights in Cyprus. In: Merten D., Papier H. J. (eds.) Handbook of fundamental rights in Germany and Europe. C.F. Müller Verlag, Heidelberg.

Kombos C., Pantazi Lambrou A. (2012) Cyprus. In: Laffranque J. (ed.) The Protection of Fundamental Rights Post-Lisbon, Reports of the XXV FIDE Congress Tallinn 2012, Vol. 1, Tartu University Press, Tallinn, pp. 303-354.

Kyriakou N. (2010) National Judges and Supranational Laws on the Effective Application of the EC Law and the ECHR: The Case of Cyprus. Available at SSRN: http://ssrn.com/abstract= 1623560.

Laulhé Shaelou S. (2010a) The EU and Cyprus: principles and strategies of full integration. SEUR vol. 3. Martinus Nijhoff, Leiden.

Laulhé Shaelou S. (2010b) 'Back to reality': the implications of EU membership in the constitutional legal order of Cyprus. In: Lazowski A. (ed.) Brave new world: application of EU law in the new member states. T.M.C. Asser Press, The Hague.

Laulhé Shaelou S. (2011) Market freedoms, fundamental rights and the European public order. YEL 30(1):298-357.

Laulhé Shaelou S. (2013) The EU in crisis. Myths and Realities. Paper presented at the seminar 'Cyprus in the eyes of the storm: legal implications of the economic and financial crisis'. UCLan Cyprus, 27 June 2013.

Lazowski A. (ed.) (2010) Brave new world: application of EU law in the new member states. T.M.C. Asser Press, The Hague.

Legrand P. (2002) Public law, Europeanisation, and convergence: can comparatists contribute? In: Beaumont P., Lyons C., Walker N. (eds.) Convergence and Divergence in European Public Law. Hart Publishing, Oxford, pp. 225 et seq.

Loizou A. (2001) The Constitution of the Republic of Cyprus. Nicosia. 
Lycourgos C. (2010) Cyprus Public Law as Affected by Accession to the EU. In: Kombos C. (ed.) Studies in European Public Law. Sakkoulas, Athens, pp. 101-115.

Lycourgos C. (2014). Preliminary reference to the Court of Justice of the European Union - Law and practice in Cyprus ten years after accession to the EU (March 2014, unpublished study) (on file with the author).

Nicolaou I. (2000) The Control of the Constitutionality of the Laws and the Separation of Powers of the State Institutions of Cyprus. Sakkoulas, Athens.

Paraskeva C. (2015) Cypriot Constitutional Law: Fundamental Rights and Freedoms. Nomiki Bibliothiki, Athens.

Pikis G. (2006) Constitutionalism - Human Rights - Separation of Powers. Martinus Nijhoff, Leiden.

Polyviou P. (2013) Cyprus on the Edge: a Study in Constitutional Survival. Nicosia.

Polyviou P. (2015a) Cyprus: A Study in the Theory, Structure and Method of the Legal System of the Republic of Cyprus. Nicosia.

Polyviou P. (2015b) Ibrahim: The Doctrine of Necessity and the Republic of Cyprus. Nicosia.

Stefanou E. (2011) Rights of suspects in Cyprus. Speech delivered at the meeting of the European Criminal Bar Association, 24 September 2011. http://www.kscp.com.cy/documents/ SUSPECTS_RIGHTS_24092011.pdf.

Stefanou E., Kapardis A. (2006) The first two years of fiddling around with the implementation of the EAW in Cyprus. Cyprus and European Law Review 2:258 et seq.

Soulioti S. (2006) Fettered Independence: Cyprus 1878-1964 vol.1: The Narrative. Minnesota Mediterranean and East European Monographs, Minneapolis.

Tornaritis C. (1968) The Social and Economic Rights Under the Law of the Republic of Cyprus. In: Mélanges Marcel Bridel: recueil de travaux. Imprimeries Réunies, Lausanne, pp. 533-556.

Tornaritis C. (1980) Cyprus and its Constitutional and Other Problems. Nicosia.

Tsadiras A. (2007) Case note. CML Rev. 44:1515 et seq.

Trimikliniotis N. (2013) Cyprus National Report 2012-2013. Network on free movement of workers. http://works.bepress.com/nicos_trimikliniotis/41/.

Open Access This chapter is licensed under the terms of the Creative Commons Attribution 4.0 International License (http://creativecommons.org/licenses/by/4.0/), which permits use, sharing, adaptation, distribution and reproduction in any medium or format, as long as you give appropriate credit to the original author(s) and the source, provide a link to the Creative Commons license and indicate if changes were made.

The images or other third party material in this chapter are included in the chapter's Creative Commons license, unless indicated otherwise in a credit line to the material. If material is not included in the chapter's Creative Commons license and your intended use is not permitted by statutory regulation or exceeds the permitted use, you will need to obtain permission directly from the copyright holder. 